\title{
3. A SYNOPSIS OF THE BAHAMAS DRILLING PROJECT: RESULTS FROM TWO DEEP CORE BORINGS DRILLED ON THE GREAT BAHAMA BANK ${ }^{1}$
}

\author{
G.P. Eberli, ${ }^{2}$ P.K. Swart, ${ }^{2}$ D.F. McNeill, ${ }^{2}$ J.A.M. Kenter, ${ }^{3}$ F.S. Anselmetti, ${ }^{2}$ L.A. Melim, ${ }^{2}$ and R.N. Ginsburg ${ }^{2}$
}

\begin{abstract}
Two continuous cores (Unda and Clino) drilled during the initial phase of the Bahamas Drilling Project on top of the western Great Bahama Bank (GBB) penetrated proximal portions of prograding seismic sequences. As such, these cores provide the shallow-water record of sea-level changes and fluid flow of the Bahamas Transect that was completed with the deeper water sites of Ocean Drilling Program (ODP) Leg 166 in the Straits of Florida. The record of several hierarchies of sea-level fluctuations is identified in the lithology and log signature of two core borings (Unda and Clino), and the nature of fluids responsible for diagenetic alteration is interpreted from formation waters and the stable isotope signal of the sediments and rocks.

Facies successions document that several hierarchies of changes in relative sea level are responsible for pulses of progradation. These pulses are seen on seismic data as seismic sequences and in the cores as depositional successions. On the platform, the boundaries of the depositional successions are indicated by subaerial exposure, changes in facies, and diagenetic overprint. On the slope, the sequence boundaries are marked by major discontinuity surfaces within the depositional successions consisting mainly of fine-grained skeletal and nonskeletal sediments. These discontinuity surfaces are characterized by hardgrounds that are overlain by 7 - and 28-m-thick, coarser grained packages containing sand-sized blackened lithoclasts, planktonic foraminifers and minor amounts of platform-derived grains. The coarser grained intervals are interpreted as deposits during relative sea-level lowstands, while the fine-grained sediments are interpreted as highstand deposits.

Higher order sea-level changes are recorded in the rocks and in the geophysical logs. On the platform top, these changes are recorded in shallowing-upward cycles bounded by exposure horizons. On the slopes, higher order sea-level changes are recognized by facies variations, whereby intervals of coarser grained sediments in the periplatform ooze indicate sea-level falls. The change in sedimentation rate and hydrology during these intervals results in the formation of firmgrounds. The intervals are well recognized as sharp peaks on the gamma-ray and velocity logs. The lower permeability on top of these intervals is likely to separate the fluid flow into several levels within each sequence and influence later patterns of diagenesis.

The next higher order of cyclicity is represented by alternations $(0.3-1 \mathrm{~m})$ of coarser and finer grained beds within the coarse-grained intervals. Because of their relatively thin nature and low contrast in rock properties, these high-frequency cycles are not recorded in the logs.

The slope portions of Unda and Clino yield several age diagnostic foraminifers and nannofossil marker species. Although low in abundance, these microfossils are good indicators of depositional age and provide the base for age determination. By combining micropaleontology, strontium-isotope stratigraphy, and magnetostratigraphy, a chronostratigraphy is obtainable in the prograding margin of GBB. The chronostratigraphy helps assess the stratigraphic evolution of the Great Bahama Bank margin, the timing of sea-level changes observed in the sedimentary record, and the synchroneity of the seismic sequence boundaries.

The correlation of the rock with the seismic record not only confirms some of the major assumptions of the sequence stratigraphic concept but also showed some of the limitations when using sequence stratigraphy as a dating tool. The assumption that seismic reflections follow depositional surfaces (i.e., time lines) is indicated by two lines of evidence. The combination of changes in composition and diagenesis produces the necessary impedance contrasts for the imaging depositional unit boundaries as seismic reflections. In addition, chronostratigraphic dating shows no crossing of seismic reflections with time lines. The inability to recognize condensed or expanded sections causes problems when dating sequences solely by correlation to the global cycle chart. For example, the condensed interval in the early Pliocene falls below seismic resolution, whereas the thick Quaternary sequences are of different duration than the ones shown on the global chart of Haq et al. (1987).

Geochemical data from the rocks and fluid samples taken during the drilling provide abundant evidence of the existence of fluid flow within the margin of Great Bahama Bank. Despite pervasive alteration and marine cementation, pore water analyses in the upper $100 \mathrm{~m}$ show an essentially isochemical profile suggesting the active flushing of seawater through this interval. Below $100 \mathrm{~m}$ in both cores, there are large increases in the concentration of nonconservative elements such as $\mathrm{Sr}$, indicating dissolution and cementation processes.
\end{abstract}

\section{INTRODUCTION}

Isolated carbonate platforms, like those of the Bahamian archipelago, are good indicators of sea-level changes. The rationale for the use of such platforms as sea-level indicators are (a) sediment producing organisms maintain the surface of these platforms near sea level (Kendall and Schlager, 1981) and, (b) such platforms are able to keep

${ }^{1}$ Eberli, G.P., Swart, P.K., Malone, M.J., et al., 1997. Proc. ODP, Init. Repts., 166: College Station, TX (Ocean Drilling Program).

${ }^{2}$ Division of Marine Geology and Geophysics, University of Miami, 4600 Rickenbacker Causeway, Miami, FL 33149, U.S.A. geberli@ rsmas.miami.edu

${ }^{3}$ Faculteit der Aardweetenschappen, Vrije Univeristeit, De Boleleaan 1085, 1081 HV Amsterdam, Netherlands. up with most sea-level rises (Schlager, 1981). The Great Bahama Bank (GBB) is considered to be such a dipstick of sea level in the Atlantic. In addition, the results of Ocean Drilling Program (ODP) Leg 101 (Austin, Schlager, et al., 1988; Austin, Schlager, Palmer, et al., 1986) and the re-examination of the Great Isaac-well on northwestern GBB (Schlager et al., 1988) have indicated tens of kilometers of progradation of the bank since the Miocene. These findings were confirmed by the first multichannel seismic data from the top of GBB that documented the westward progradation of the bank of more than $25 \mathrm{~km}$ into the Straits of Florida since the Miocene (Eberli and Ginsburg, 1987; 1989). Progradation occurred in pulses seen on the seismic lines as laterally stacked sequences. Geometries within these prograding sequences suggested that the pulses of progradation were sea-level controlled. Downstepped flat platform margins gave indica- 
tions for sea-level lowering, while downlapping of reflections onto these surfaces indicated platform flooding followed by progradation. Thus, the magnitude and timing of sea-level changes are potentially recorded within these prograding sequences. The magnitude can be deciphered by measuring the amount of downstepping of the platform margin and subsequent aggradation (Eberli and Ginsburg, 1989). The timing can be determined by dating the unconformities separating the sequences (Vail et al., 1977; Christie-Blick et al., 1990).

In addition to the sea-level objectives GBB also offered the opportunity to study the diagenetic alteration in the platform interior and fluid flow through an isolated carbonate platform. Previous work (Allan and Matthews, 1982) has suggested that the diagenetic environment of the flat-topped platform was dominated by meteoric diagenesis, especially during the Neogene when repeated sea-level changes exposed the platform for long periods of time. Submarine cements in the shallow subsurface of platform interiors, although rare, have been documented (Beach, 1993). Geochemical signature reported by Melim et al. (1995) not only supports the influence of marine fluids, but suggests that this influence is much more pervasive than previously recognized.

To solve questions regarding the origin of the Bahamas Platform, diagenesis and fluid flow, the Bahamas Drilling Project (BDP) was initiated by the Comparative Sedimentology Laboratory of the University of Miami. The two cores, Unda and Clino, retrieved in 1990 from a self-propelled jack-up barge on top of GBB serve as the two proximal sites of the Bahamas Transect that was completed during ODP Leg 166.

\section{Background of the Bahamas Drilling Project}

Using standard seismic stratigraphic techniques, seismic sequences were identified within the prograding margin of western GBB (Eberli and Ginsburg, 1989). Schlager et al. (1988) identified four biostratigraphic horizons within the Cretaceous/Tertiary section of the Great Isaac-1 exploratory well and correlated them to seismic lines. The youngest age reported in the well was middle Miocene at a depth of $800 \mathrm{~m}$. The reflector above this depth was identified by Schlager et al. (1988) as a sequence boundary which, by jump correlation, coincided with the base of the prograding package identified by Eberli and Ginsburg (1989). By comparing the regional onlap curve constructed from these upper Miocene to Holocene sequences with the onlap pattern on the global cycle chart of Haq et al. (1987), they proposed tentative ages for these Bahamian sequences.

Results from the BDP allowed the sequence stratigraphic interpretation and the sequence stratigraphic concept in general to be tested. The sequence stratigraphic objectives of the drilling were to (1) provide facies information for the seismic sequences, (2) establish the cause for the seismic reflections in these pure carbonate sequences, (3) test if seismic sequence boundaries and inferred systems tracts coincide with the appropriate facies changes, (4) determine ages of sequences boundaries, and (5) test the interpretation that the prograding sequences are sea-level controlled, and if so provide a reference curve of relative changes in sea level for the late Miocene to the Holocene.

In addition to the sequence stratigraphic objectives, the cores from the top the platform offered an ideal opportunity to evaluate the diagenetic alteration and the fluid flow within the platform. Exhumed ancient platforms are generally extensively diagenetic altered, in some cases completely dolomitized (e.g., Illing, 1959; Fritz and Jackson, 1971; Füchtbauer, 1974; Mattes and Mountjoy, 1980). Shallow core borings from San Salvador, Little Bahama Bank, and GBB indicated that the subsurface of the Bahamas has been extensively altered to low-magnesium calcite (LMC) and dolomite (Field and Hess, 1933; Newell and Rigby, 1957; Supko, 1977; Gidman, 1978; Pierson, 1982; Dawans and Swart, 1988; Vahrenkamp et al., 1991; Beach, 1993). These rocks are frequently texturally mature, yet clearly are young and have not been buried to any appreciable extent. Most models of diagenesis invoked a phase of freshwater alteration, followed by early dolomitization (Supko, 1977; Pierson, 1982; Vahrenkamp et al., 1991). There is, however, a growing realization that diagenesis under conditions associated with Pleistocene sea-level fluctuations may not be representative of pre-Pleistocene times or in deeper water settings. There is also a growing awareness that fluid flow processes in carbonate platforms are not restricted to the upper portions of the exposed platforms, but are taking place hundreds to thousands of meters below the platform surface. Little, however, was known at the time of drilling about the amount and the mechanisms for the fluid circulation in platforms. The BDP provided an opportunity to examine formation fluids and diagenetic fabrics from portions of a carbonate platform which had never been exposed to subaerial conditions.

To achieve all these goals, a multidisciplinary study was conducted that included the following disciplines: sedimentology, diagenesis, geochemistry, petrophysics, lithostratigraphy, biostratigraphy, and magnetostratigraphy.

\section{Drilling Locations and Operations of the Bahamas Drilling Project}

Two sites, Unda and Clino, were drilled along a seismic line originally acquired by Western Geophysical (henceforth known as the Western Line). In this location the thick sequences of the prograding western margin yielded a high chronostratigraphic resolution (Figs. 1-3). Hole Clino was positioned to penetrate the series of inclined reflections which image slope deposits underneath a thin, upper Pleistocene and Holocene platform succession. Hole Unda, $8.5 \mathrm{~km}$ farther onto the platform, was located to recover the interval of platform margin deposits where sea-level falls were expected to be recorded by subaerial exposure horizons. The target horizon was the base of a series of high-amplitude reflections that, at the location of Unda, pinch out against a set of discontinuous reflections interpreted as a marginal reefal buildup by Eberli and Ginsburg (1989). Above this target horizon, which was believed to be the top of the middle Miocene, eight prograding sequences were identified.

The drilling was performed between March and May 1990 from a self-propelled jack-up barge in approximately $7 \mathrm{~m}$ of water using conventional diamond drilling technology. Continuous cores were taken using a wire-line system with a triple tube core barrel $3.05 \mathrm{~m}$ long that recovered cores of $6.3 \mathrm{~cm}$ in diameter. Core Clino was

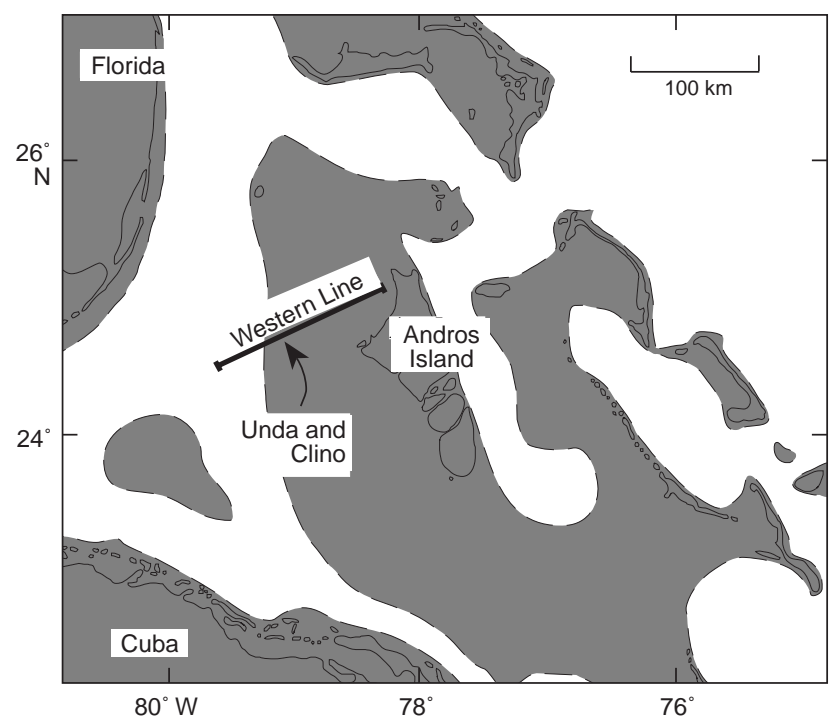

Figure 1. Location map of the drill sites Unda and Clino on the Great Bahama Bank. 


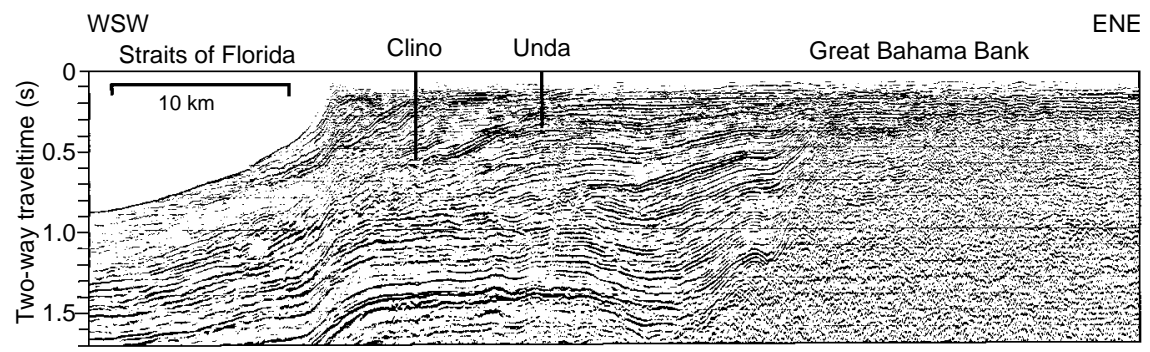

Figure 2. Location of Unda and Clino on seismic line. Unda was positioned in a proximal location to penetrate mostly flat-lying reflections. Clino is situated $8.5 \mathrm{~km}$ farther westward above inclined upper slope reflections. The target horizon was the base of a high-amplitude reflection horizon believed to be the top of the middle Miocene. Unda penetrated $454.15 \mathrm{~m}$ and Clino 677.71 $\mathrm{m}$ below the mud pit datum (7.3 m, above sea level).

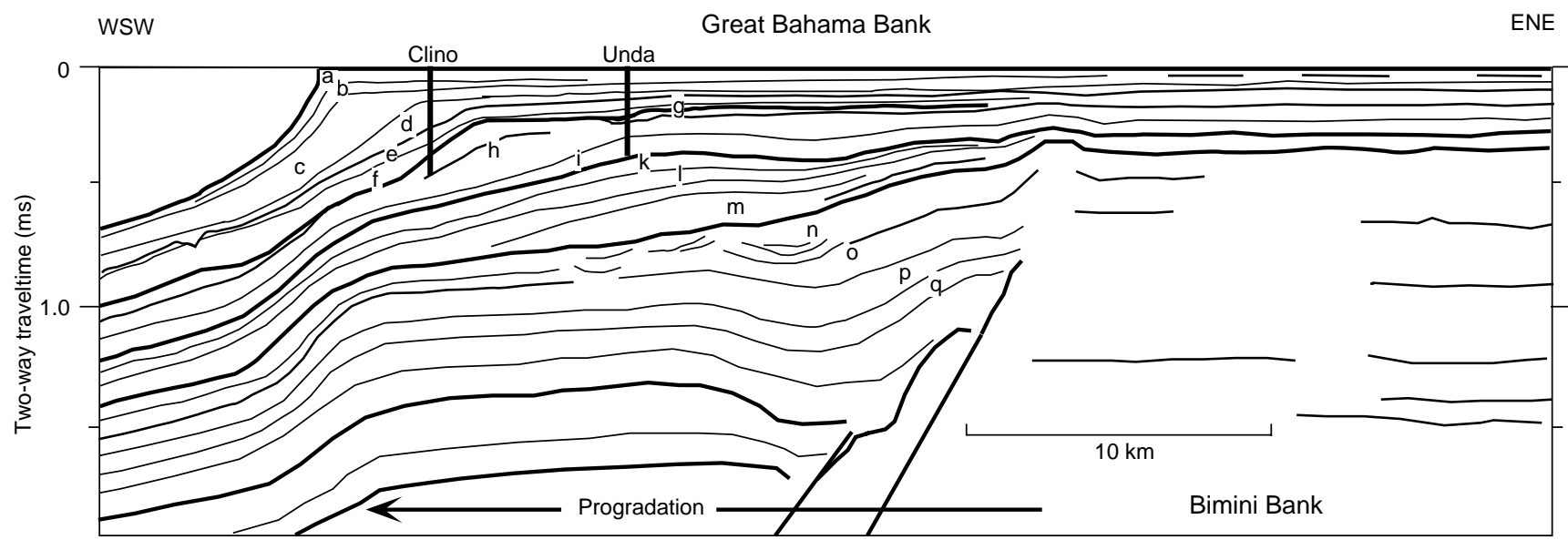

Figure 3. Line drawing of interpreted seismic line with the seismic sequences. The geometries of the upper Miocene to Holocene seismic sequences are generally sigmoidal with a steepening of the foresets in the younger sequences. Sequences $a-i$ were penetrated by the two holes Unda and Clino.

drilled $677.71 \mathrm{~m}$ below the mud pit datum $(7.3 \mathrm{~m}$, above sea level). Recovery in Clino averaged $80.8 \%$. Core Unda was drilled $454.15 \mathrm{~m}$ below mud pit (5.2 m, above sea level). Recovery in Unda averaged $82.9 \%$. After coring, both holes were logged with downhole tools for density, sonic velocity, natural gamma, neutron, caliper, inclination, and some shear-wave velocities. A continuous vertical seismic profile (VSP) was shot for an accurate time-depth conversion.

\section{Sequence Analysis}

Prior to drilling a sequence analysis was performed within the prograding package of western GBB (Eberli and Ginsburg, 1989). Since the original study, improvements in the processing of seismic data have helped to refine this sequence stratigraphic analysis. For the original study, only the top 1.1 seconds (s) two-way traveltime (TWT) of the grid of seismic lines and the top $1.7 \mathrm{~s}$ (TWT) of the Western Line were available. These lines were processed for industrial needs with deep target horizons. Exxon Production Research reprocessed the key line (Western Line) with a special emphasis on the top $2 \mathrm{~s}$ (TWT). The prograding package was originally separated in individual sequences by using mostly onlap patterns (Eberli and Ginsburg, 1989). On the improved section erosional truncation of reflections at the platform margin became visible. As a result, the sequences were separated using erosional truncation surfaces in four cases and onlap relationships in the others. In addition, sequence boundaries could be placed with more confidence and helped to refine the position of the three sequence boundaries $f / g, g / h$, and $h / i$.

\section{Sequence Geometries as Indicators of Sea-Level Changes}

The prograding sequences display a generally sigmoidal shape with increased steepening of the foresets in the younger sequences that led to the modern, steep platform margin (Fig. 3). In addition, the seismic sequences display variable internal architecture. Sequence $h$ above the target horizon forms a prograding clinoform package on the underlying sequence boundary. Unda is situated on flat topset beds and Clino on the front of the sigmoid shoulder (Figs. 2, 3). The overlying Sequence $g$ is a thin sequence that is developed toward the platform and farther basinward. At the shelf break and at drilling location Clino, Sequence $g$ merges seismically with the top of Sequence $h$. Sequence $f$ is also a thin sequence on the shelf margin but thickens basinward west of drill site Clino. Sequences $f$ and $g$ continue to the inner shelf area where they onlap Bimini Bank approximately $18 \mathrm{~km}$ farther to the east, documenting that no aggradation occurred during this time on the adjacent bank.

The overlying Sequence $e$ reaches again onto the platform. Sequence $e$ shows a backstepping pattern and a thick topset unit. While aggradation was high, progradation in this sequence is minimal. In contrast, the next younger sequence, $d$, has a thin topset unit but well developed prograding clinoforms that end on a distinct downlap surface. The next sequence, $c$, has a thin topset, but an impressive package of prograding clinoforms that advances the platform margin more than $4 \mathrm{~km}$ basinward. Within the prograding part of this sequence the platform margin changes its morphology as the gently inclined foresets start to steepen and transform the ramp-like margin into a steepsided morphology. The platform margin declivity further increases in the two youngest sequences, $a$ and $b$, which are characterized by thin topsets and steep foresets.

The geometry and internal architecture of the eight sequences is interpreted to reflect the following general relative sea-level history. A lowering of sea level during the deposition of the basal Sequence $h$ led to the establishment of buildups on the former slope, creating probably a barrier reef $10 \mathrm{~km}$ basinward of the former platform edge. This major progradation was followed by a sea-level rise that did not create accommodation space on the platform during the rise, but instead formed deep incisions during its lowering phase. The two basal sequences are therefore thought to have been deposited during a longterm lowering of sea level. The subsequent sea-level rises in Sequences $f$ and $e$ were of high amplitude and probably of a relatively fast rate, which forced the platform margin to backstep. With a de- 
crease of the rate of rise, the accommodation space was filled by sediments in an aggradational-progradational pattern. This high, elevated platform was overstepped only slightly by the subsequent sea-level rises and as a result, deposits in Sequences $c, b$, and $a$ are mostly stacked laterally, producing major progradation.

Based on jump-correlation of a seismic horizon dated as middle Miocene by Schlager et al. (1988) at the base of a similar prograding package at the northwestern tip of GBB to the location of the Western Line and seismic stratigraphic analysis, tentative ages were proposed for these prograding pulses (Eberli and Ginsburg, 1989). The age of the basal sequence boundary was believed to be $10.5 \mathrm{Ma}$, and the three oldest sequences to be upper Miocene. From the five overlying sequences, four were thought to be Pliocene and one Pleistocene in age. The Holocene was assumed to be too thin to be imaged on the multichannel seismic line. These ages were assigned using the seismic geometries and a correlation with the Haq et al. (1987) curve. The BDP was designed to test this age model, and by doing so, the sequence stratigraphic concept.

\section{RESULTS OF THE DRILLING}

Detailed results of sedimentology, chronostratigraphy, petrology and geochemistry, sequence stratigraphy, and petrophysics have been published in a series of papers contained in an SEPM publication. The following is a summary of these findings.

\section{Sedimentology}

The two core borings revealed multiple, punctuated depositional successions with different frequencies that are interpreted as the sedimentary record of relative sea-level changes (Fig. 4). In the shallow portions, caliche crusts, karst, and black pebble conglomerates are taken as indicators of subaerial exposure horizons, while, in the slope section, changing sediment composition is correlated to fluctuations in sea level.

\section{Unda}

Unda consists of three intervals of shallow-water platform sands and reefal deposits (108.1-8.6 m, 354.7-292.8 m, 453-443.5 m) that alternate with sand and silt-sized deeper marginal deposits (Fig. 4). All three platform/reefal intervals (23\% of core Unda) show evidence of repeated episodes of shoaling and/or subaerial exposure. In the uppermost platform/reefal unit a layered subunit overlies a reefal unit. The layered cap has a total thickness of $45.4 \mathrm{~m}$ and consists of 14 meter-scale paracycles of bioturbated shallow-water carbonates sandwiched between exposure horizons. The sediments are composed of fine-grained, nonskeletal mudstone to wackestone and fine to coarse sand-sized grainstone to packstone with varying proportions of skeletal and nonskeletal components. Grain types are predominantly peloids, coated grains, benthic foraminifers, mollusks, and worm tubes. This layered cap is highly porous with centimeterscale vugs and moldic porosity. The facies of the layered cap are similar to the Lucayan Formation described from other shallow cores on GBB (Beach and Ginsburg, 1980; Beach, 1993). These facies cap a reefal unit that extends to a depth of $108.1 \mathrm{~m}$. The reefal unit developed from a carbonate sand unit in which molds of several pieces of flat-lying, branching coral, Stylophora spp, mark the beginning of the reefal succession. The reefal interval displays an overall shoaling-upward trend in the coral assemblages (Budd and Kievman, in press). The middle platform unit $(354.7-292.8 \mathrm{~m})$ is a 70-m-thick, dolomitized interval of shallow-water deposits grading upsection from fine-grained sediments into skeletal packstones and coral interval. The skeletal packstone contains mostly coralgal, coral, and mollusk skeletal debris (Fig. 4). Coral assemblages within the reefal interval indicate an overall deeper reef environment (Budd and Kievman, in press). The lowest platform interval $(453-443.5 \mathrm{~m})$ is a coarsegrained skeletal to nonskeletal grainstone to rudstone characterized by a 3-m-thick coarsening-upward sequence and cross bedding capped by sharp surfaces that are bored and overlain by mudstone layers.

The intervals between the three platform/reefal units consist of fine-grained skeletal to mixed skeletal-nonskeletal silt and sand. More than $40 \%$ of Unda is composed of these fine-grained (less than $250 \mu \mathrm{m})$ skeletal and nonskeletal wackestone to grainstone that alternate with coarse-grained intervals. The sediments are light cream to tan in color, generally monotonous, and with the exception of ichnofossils, are structureless. Fine-grained intervals have thicknesses between 5 and $35 \mathrm{~m}$ with gradational boundaries, although three abrupt sharp boundaries are observed at $270.36 \mathrm{~m}, 292.82 \mathrm{~m}$, and $376.6 \mathrm{~m}$ with the underlying sediments. Both fine- and coarse-sand intervals are very similar in grain composition; $60 \%$ nonskeletal and $40 \%$ skeletal grains. There is little downhole variation in texture, composition, and sedimentary structures within these slope units, but they are sometimes punctuated by $\mathrm{Fe} / \mathrm{Mn}$-hardgrounds or condensed layers with concentrations of phosphate and/or reworked benthic foraminifers. Below $443.49 \mathrm{~m}$, the sediments are made up of alternating laminated wackestone to packstone, and porous to tightly cemented pack- to grainstone, similar to that of the deeper interval in Clino (below $367.03 \mathrm{~m}$ ).

\section{Clino}

Three major lithologic intervals are observed in Clino (Fig. 4): (1) an upper interval of shallow-water platform and reefal deposits (197.44-21.6 m); (2) an intermediate interval that is predominated by fine-grained nonskeletal sediment containing thin skeletal intercalations (367.03-197.44 m); and (3) a deeper interval that is predominated by a mixture of fine-grained skeletal and nonskeletal sediment with intercalations of thin skeletal layers $(677.27-367.03 \mathrm{~m})$.

The shallow platform section $(98.45-21.6 \mathrm{~m})$ has at least seven paracycles, each of which is capped by a horizon of subaerial exposure. In the reefal unit (197.44-98.45 m), there is an upward progression from deep reef/fore slope to fore reef to reef crest $(173 \mathrm{~m})$ and finally, back reef.

The nearly $504 \mathrm{~m}$ of the underlying fine-grained, slope interval (677.27-197.44 m) is composed of $80 \%$ of monotonous sediment of fine-sand to silt-sized skeletal and peloidal grains. The interval between 367.03 and $197.44 \mathrm{~m}$ consists of alternating layers, decimeter to meter thick, of mudstone, peloidal packstone to grainstone, and minor skeletal packstone to grainstone. These layers are predominantly nonskeletal (peloidal) in composition and nearly devoid of planktonic foraminifers. In contrast, below $367.03 \mathrm{~m}$, the sediment is made up of meter-scale, alternating laminated wackestone to packstone, and porous to tightly cemented packstone to grainstone. Grain composition is mixed peloids and skeletal grains, with between $5 \%$ and $10 \%$ planktonic foraminifers.

The fine-grained nonskeletal to skeletal sediments are intercalated by 12 intervals of coarse-grained skeletal packstone to grainstone. Two of these intercalations overlie discontinuity surfaces that indicate significant periods of nondeposition and/or erosion on the slope, at 536.33 and $367.03 \mathrm{~m}$, respectively. The discontinuity surface at $536.33 \mathrm{~m}$ is phosphatic hardground; the one at $367.03 \mathrm{~m}$ is an erosional surface. The intercalation starting above $367.03 \mathrm{~m}$ is also associated with a major change in composition of the background sediment from predominately mixed skeletal-peloidal below, and nonskeletal above. Below $367.03 \mathrm{~m}$, the intercalations are made up of reworked planktonic foraminifers some margin-derived skeletal grains, and phosphatic grains. Between 367.03 and $197.44 \mathrm{~m}$, they are predominantly margin-derived skeletal grains.

The intercalations of skeletal packstones into thick intervals of fine-grained "background" sediment form a slope section consisting of three larger sedimentary successions with an average thickness of 

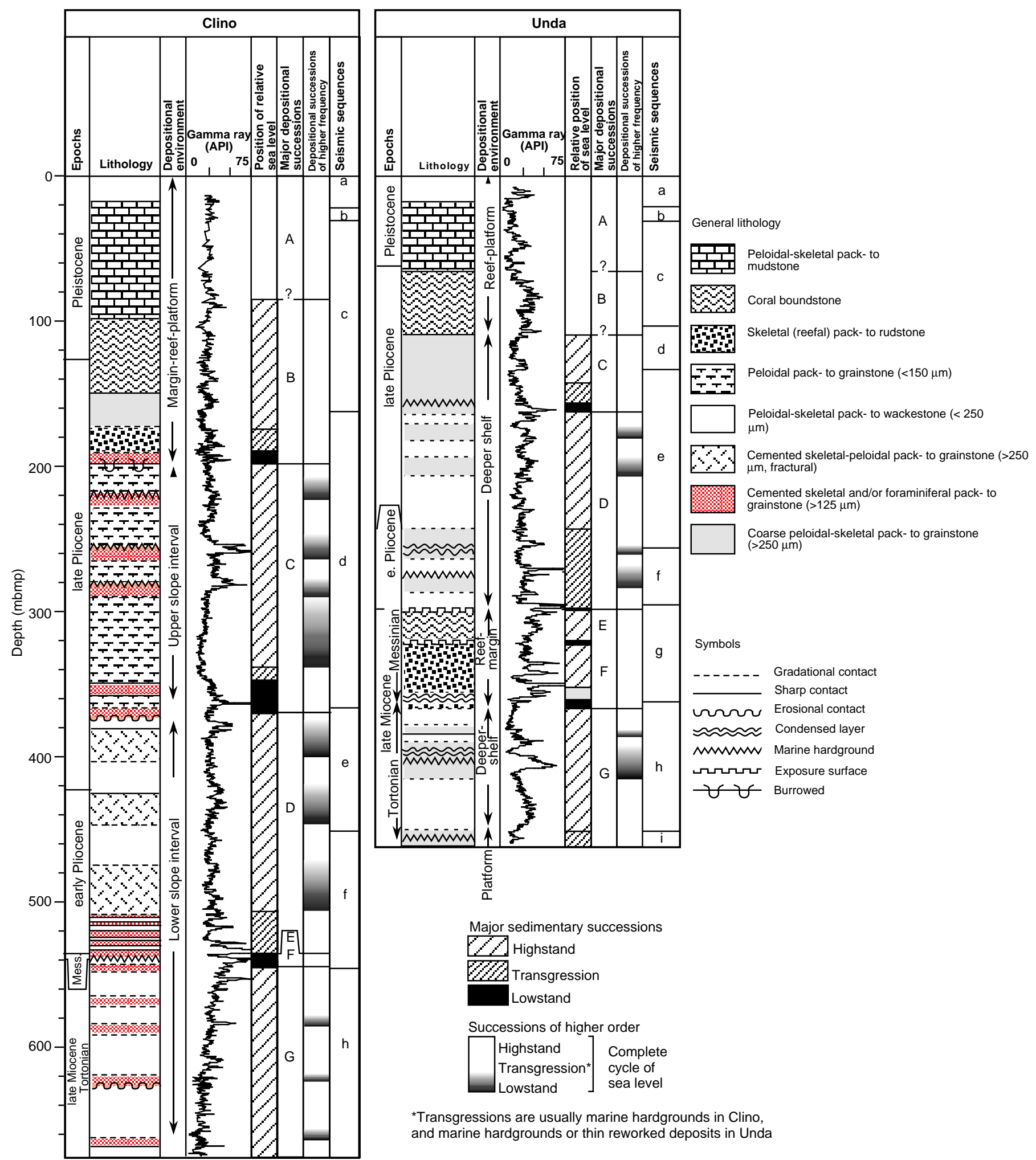

*Transgressions are usually marine hardgrounds in Clino, and marine hardgrounds or thin reworked deposits in Unda

Figure 4. Lithologic logs of Unda and Clino. The depositional sequences can be grouped in two orders of succession, interpreted as the product of different orders of sea-level changes (Kenter et al., in press). As a result of scale considerations, not all surfaces are shown. mbmp = meters below mud pit. 
$\sim 170 \mathrm{~m}$, each containing two to three smaller scale successions with a thickness ranging from 25 to $90 \mathrm{~m}$ (Fig. 4). The sediment composition of the intercalations with reworked foraminifers, lithoclasts, and coarse skeletal debris is indicative of deposition during sea-level lowstands. Flooding events are expressed as marine hardgrounds and/or deposits of reworked material. Sedimentation during times when the platform was flooded is characterized by the fine-grained mixed skeletal and peloidal packstones and wackestones.

\section{Chronostratigraphy}

Platform-top facies are extremely difficult to date, mainly as a result of the absence of sufficient age-diagnostic shallow-water fossils, lack of open-ocean biostratigraphic markers, and relatively early and pervasive diagenetic alteration (Beach and Ginsburg, 1980; Williams, 1985). Recently, two techniques have been successfully applied to constraining the depositional age of shallow-water carbonates, that of strontium-isotope stratigraphy (Swart et al., 1987; Ludwig et al., 1988) and magnetostratigraphy (McNeill et al., 1988; Aïssaoui et al., 1990). By drilling at the western margin of GBB, it was anticipated that the slope depositional environment and the proximity to the open ocean would also provide adequate foraminifers and nannofossil markers. Indeed, the slope portions of Unda and Clino yielded several age diagnostic foraminifers and nannofossils marker species. Although low in abundance, these microfossils were good indicators of depositional age and provided a powerful tool for age determination. By combining micropaleontology, strontium-isotope stratigraphy, and magnetostratigraphy, chronostratigraphy was obtainable in the prograding margin of GBB.

\section{Biostratigraphy}

Benthic and planktonic foraminifers and calcareous nannofossils were recovered throughout Unda and Clino. Biostratigraphic investigations were limited by poor microfossil preservation, pervasive diagenesis, and the prevalent effects of downslope transport (Lidz and Bralower, 1994; Lidz and McNeill, 1995a and 1995b). Some of these problems pertained to the planktonic foraminifers, some to the nannofossils, and some to both groups. The planktonic foraminifers provided a more detailed series of biohorizons than did the calcareous nannofossils, yet, originally, there was no straightforward age interpretation for either hole (Lidz and Bralower, 1994). An understanding of the slope dynamics and depositional system proved to be critical toward interpretation of the biostratigraphic data, as extreme dilution by platform-derived sediments occurs during margin progradation. As such, the occurrence and highest abundance of microfossils was restricted to the thin units of pelagic-rich sediment, deposited during times when platform sediment supply was greatly reduced (Lidz and McNeill, 1995a). Consequently the conventional open-ocean biostratigraphic approach had to be used with caution due to the possibility of time-erroneous first- and last-appearance datums. These biostratigraphic datums can be either premature last occurrences (LO) or delayed first occurrences (FO) resulting from the overwhelming dilution by shallow-platform derived sediment or change to shallow-water facies.

The biostratigraphic datums that are age diagnostic and believed to be reliable are all, with one exception, taken from the study by Lidz and McNeill (1995a). The one exception is the revision of the first occurrence of Globorotalia margaritae in the lower section of core Clino. Based on new data collected during ODP Leg 166, this occurrence at $634.9 \mathrm{~m}$ in Clino probably represents an evolutionary precursor to the recognized first appearance $(5.6 \mathrm{Ma})$ of the species (D. Kroon, pers. comm., 1996) in which G. margaritae became very abundant. The biostratigraphic datums are shown on Figure 5 for core Clino, modified from figure 2 of Lidz and McNeill (1995a), and on Figure 6 for core Unda (a modified version of figure 4 of Lidz and McNeill (1995a). The ages are after Berggren et al., 1985.

\section{Clino}

The bottom of core Clino penetrated upper Miocene sediments placed within foraminifers Biozone N16/N17 (7.5-5.3 Ma), as indicated by the FO of Neogloboquadrina humerosa (7.5 Ma) at $674.8 \mathrm{~m}$. The following $90 \mathrm{~m}$ of sediments were deposited at a high sedimentation rate as indicated by the LO of Discoaster neohamatus (7.2 Ma) at $584.9 \mathrm{~m}$. A condensed interval occurs between $541.3 \mathrm{~m}$ and 531.8 $\mathrm{m}$. The base of this interval contains a hiatus of approximately $1.2 \mathrm{Ma}$ that straddles the Miocene/Pliocene boundary. The upper portion of this interval is a condensed section of early Pliocene age (Biochrons N18/N19) that is documented by the influx of 17 species that typically arise in the early Pliocene (Lidz and McNeill, 1995a). A lower upper Pliocene section (3.4-3.1 Ma) is detected between $444.7 \mathrm{~m}$ and 401.4 meters below mud pit (mbmp) based on the LO of Pullenianta obliquiloculata primalis and the FO of Globorotalia tosaeensis tenuitheca. The following $31.1 \mathrm{~m}$ of core are assigned to be $3.1-1.9 \mathrm{Ma}$ based on the concurrent FOs of Globorotalia truncatulinoides and Pullenianta obliquiloculata finalis. The upper portion of the core is placed in foraminifers Biozone N22 ranging in age from 1.9 to 1.6 Ma. The upper $200 \mathrm{~m}$ could not be dated using planktonic foraminifers or calcareous nannofossils due to the shallow-water facies and associated diagenesis.

\section{Unda}

Biostratigraphy in core Unda also relied on the data presented by Lidz and McNeill (1995a) and is summarized in Figure 6. The bottom portion of Unda can only be constrained to Biozone N16 (10.2-6.6 $\mathrm{Ma})$ due to the lack of more refined age markers and the progressive shallowing of carbonate facies up to a reefal sequence. The reefal unit is constrained in age to N17/N18 (6.6-5.5 Ma) by markers below and above as shown on Figure 6. Above the reef, the deeper water facies again allowed use of age-diagnostic markers. The middle portion of Unda ranges from N18?/N19 ( 5.5 Ma) through Biozone N21? (2.2$1.9 \mathrm{Ma}$ ), and may include part of N22 (Fig. 6). As in Clino, the upper part of core Unda, about the top $100 \mathrm{~m}$, had shallow-water facies that were not amenable to deep-sea biostratigraphic methods.

\section{Strontium-Isotope Stratigraphy}

Several models for the temporal evolution of the ${ }^{87} \mathrm{Sr} /{ }^{86} \mathrm{Sr}$ ratio in seawater have been proposed for the late Neogene (DePaolo and Ingram, 1985; DePaolo, 1986; Hodell et al., 1991; Beets, 1992; Farrell et al., 1995) and are commonly used to provide age constraints. The strontium-isotope data from cores Clino and Unda were analyzed by Swart et al. (in press, a) using a composite matrix that combines the existing, reliably dated strontium-isotope data from a number of deep-sea sites. The strontium-isotope data set was converted to a common time spacing of $100 \mathrm{k} . \mathrm{y}$. and a five sample moving average applied. Maximum and minimum ages (age range) for BDP samples were determined in the matrix by using \pm 1 standard deviation of the 0.5 m.y. moving average. For the regression equations the given $95 \%$ confidence intervals were applied to the calculated age value.

The comparison of the matrix model of Swart et al. (in press a) with existing calibrations of Hodell et al. (1990), Beets (1992) and Farrell et al. (1995) is discussed by Swart et al. (in press, a) and McNeill et al. (in press). The comparison reveals that within the error claimed for the various different approaches essentially identical ages are calculated from all the methods. Discrepancies occur only in values measured for the relatively flat parts of the ${ }^{87} \mathrm{Sr} /{ }^{86} \mathrm{Sr}$ curve (i.e., the early Pliocene) and their associated age.

In the Clino and Unda cores the sediment has undergone diagenetic alteration such as recrystallization and dolomitization (Melim et al. 1995). Swart et al. (in press, b) show that the Sr-isotopic compositions of the pore fluids, corrected for possible contamination by surface waters using tritium, indicate that the formation fluids have ${ }^{87} \mathrm{Sr} /$ 


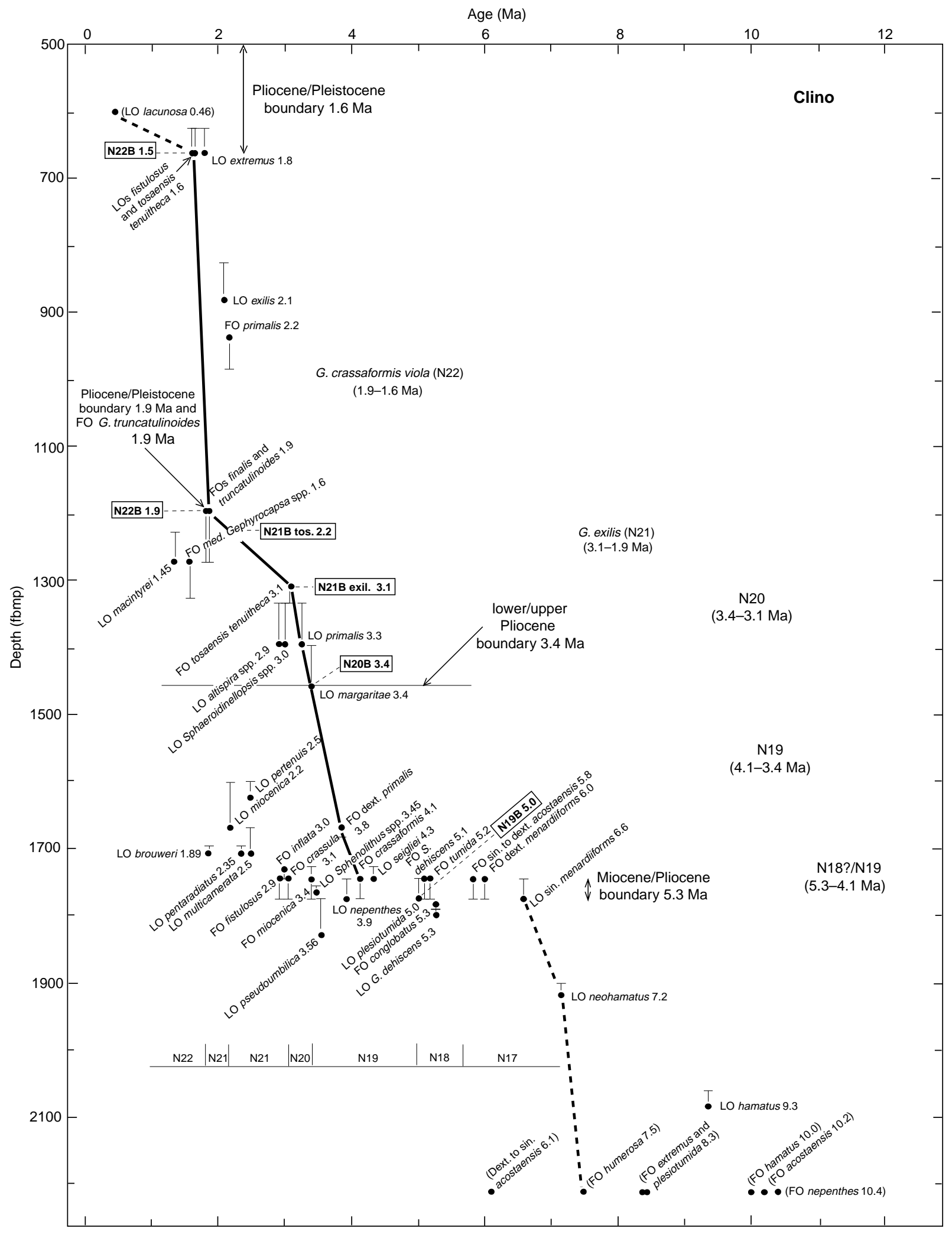

Figure 5. Biostratigraphic datums for core Clino (McNeill et al., in press). fbmp = feet below mud pit. 


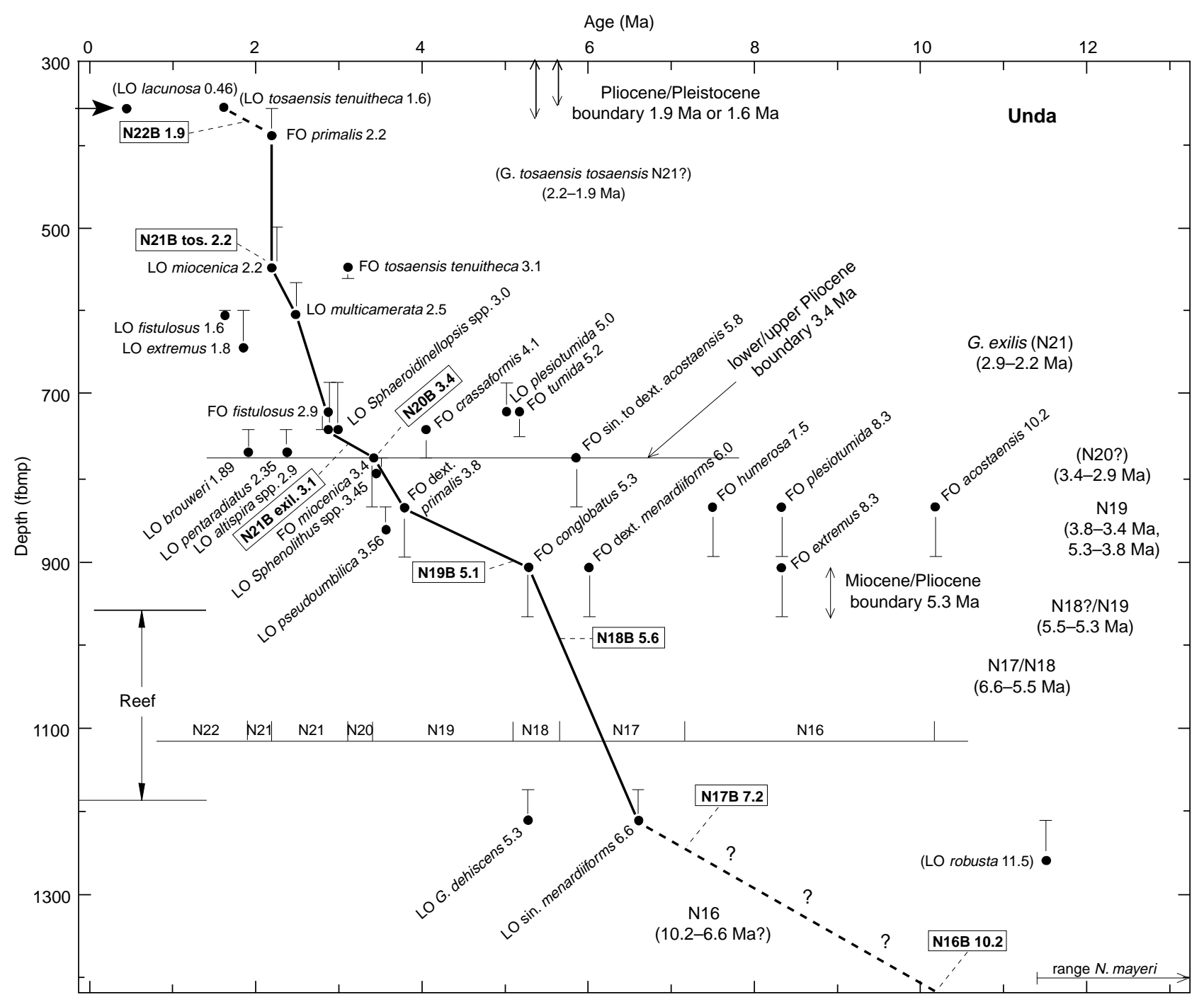

Figure 6. Biostratigraphic datums for core Unda (McNeill et al., in press). fbmp = feet below mud pit.

${ }^{86} \mathrm{Sr}$ ratios less radiogenic than modern seawater, but in all instances considerably more radiogenic than the co-occurring sediments and rocks. Assuming that similar conditions of fluid movement have been prevalent since deposition, later stage diagenetic alterations produce a rock that is more radiogenic (younger) than the parent material. Therefore, the Sr-isotope values generally yield a minimum age of deposition as bulk-rock samples reflect a combination of the isotopic value of the remaining depositional mineralogy and secondary mineralogies altered in a fluid of different isotopic composition.

\section{Clino}

Age values from the bottom portion (675-550 m) of core Clino generally fall in the flat portion (late Miocene) of the strontium-isotope curve and hence have a wide age range but generally corroborate a late Miocene age of the section (Fig. 7). Between approximately 550 and $525 \mathrm{~m}$, age ranges are better constrained to around 6.0 to 4.5 Ma. Above this level $(525-250 \mathrm{~m})$ strontium-isotope ages range usually between 2.5 and $1.5 \mathrm{Ma}$. Slightly younger ages are indicated between 250 and $120 \mathrm{~m}$. The upper portion of the core, representing reefal margin and platform-top facies, has relatively few strontium-iso- tope age constraints as a result of poor preservation of original mineralogies.

\section{Unda}

As in Clino, Unda strontium-isotope age ranges were derived using bulk rock, shell, phosphorite, and dolomite (Fig. 8). The base of Unda below about $350 \mathrm{~m}$ had a wide age range from about 11.0 to 5.5 $\mathrm{Ma}$ as a result of the low stratigraphic resolution of the strontium-isotope curve between about 8.0 and $5.5 \mathrm{Ma}$ and the greater time range associated with the confidence interval. Thus, the age of the bottom portion of Unda cannot be better resolved by strontium isotopes alone. However, one sample of a marine oyster (genus Pycnodonte?), still with the original color and mineralogy (low-magnesium calcite) at $423 \mathrm{~m}$, yielded a strontium-isotope value giving a calculated age of between $8.3 \mathrm{Ma}$ and 9.3 Ma. The age of this sample falls just before the flat portion of the curve at 8.0 to 5.5 Ma. From about 350-275 m, the isotopic values indicate an age range of about 4.0 to 6.0 Ma for most of the dolomite samples, whereas several bulk samples had values that were slightly less radiogenic and fell in the flat portion of the curve ( 8.0-5.5 Ma). From about 275 to $200 \mathrm{~m}$ age ranges again 


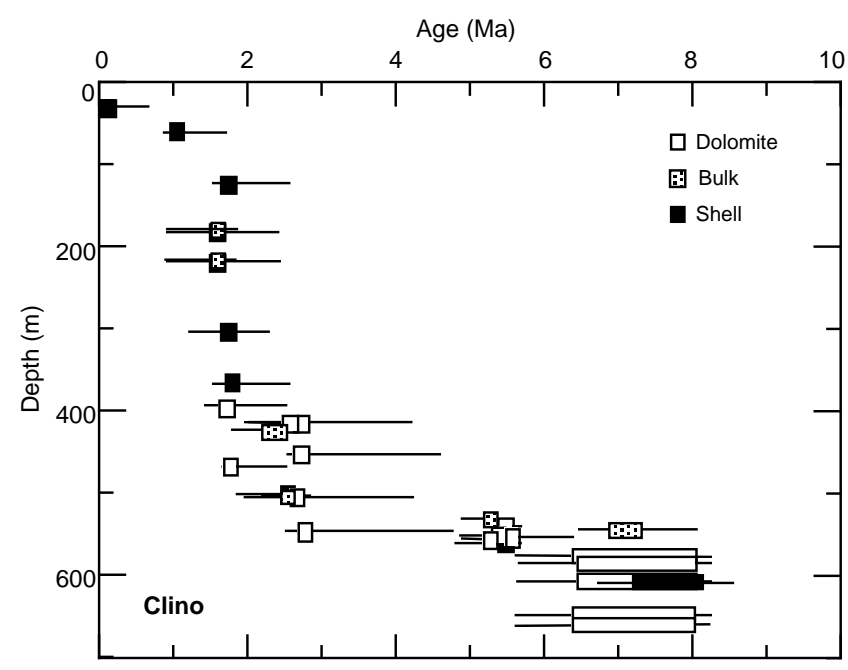

Figure 7. Ages determined from the Sr-isotopic data presented by Swart et al. (in press, a) for Clino. Error bars represent uncertainty as determined from the Sr-isotope curve.

showed a mixed result from as young as 2.0 Ma to as old as about 5.0 Ma. Dolomite ages in this interval are generally younger than ages of bulk-rock samples. Ages of several of the bulk-rock samples, as well as some of the dolomite samples, fell within the flat portion of the strontium-isotope curve ( 4.4-2.4 Ma). Above $200 \mathrm{~m}$, the age maximum and minimum fell between 2.5 Ma and 1.0 Ma. Bulk-rock, shell, and dolomite samples were fairly consistent in age within the upper portion of Unda. This similarity in age might indicate a penecontemporaneous, seafloor formation of dolomite. As with Clino, samples in the reefal and platform-top facies of Unda were limited due to intense diagenetic alteration.

\section{Magnetostratigraphy}

A magnetostratigraphic correlation to the geomagnetic polarity time scale is proposed based on the age constraints provided by foraminifers age ranges (Lidz and McNeill, 1995a), strontium-isotope age constraints (Swart et al., in press, a), and several calcareous nannofossil age ranges (Lidz and Bralower, 1994). Age constraints are summarized below for the magnetic correlation. For discussion of alternate age models, the reader is referred to McNeill et al. (in press).

\section{Core Clino}

Core Clino consisted of four major normal polarity zones separated by three major zones of reversed polarity (Fig. 9).

Section 1 (677.3 to $536.5 \mathrm{~m})$. Late Miocene. The age range in section 1 is from about 7.3 Ma near the base to about 6.7 at the top, with a condensed/hiatus overlying the section. Four primary constraints contribute to this model: (1) the FO of Neogloboquadrina humerosa $(7.5 \mathrm{Ma})$ at the base of the core; (2) at least eight strontium-isotope age ranges between about 8 and $6 \mathrm{Ma}$ in the middle and lower part of the section; (3) the strontium-isotope age $(6.0$ and $5.0 \mathrm{Ma})$ of a phosphorite crust at $536 \mathrm{~m}$ in the overlying section 2; and (4) several strontium-isotope age ranges of between $\sim 6.0$ and $5.0 \mathrm{Ma}$ in the top of section 1.

Section 2 (536.4 to $521.8 \mathrm{~m}$ ). Early Pliocene. The interval above the basal normal polarity zone shows two thin, alternating normal and reversed polarity zones (Fig. 9), which we tentatively correlate with the normal subchrons (Nunivak and Cochiti?) in the middle part of the Gilbert Chron. Biostratigraphy supports the age of this interval as being early Pliocene (Figs. 6, 9). A strontium-isotope age (6.0-5.0

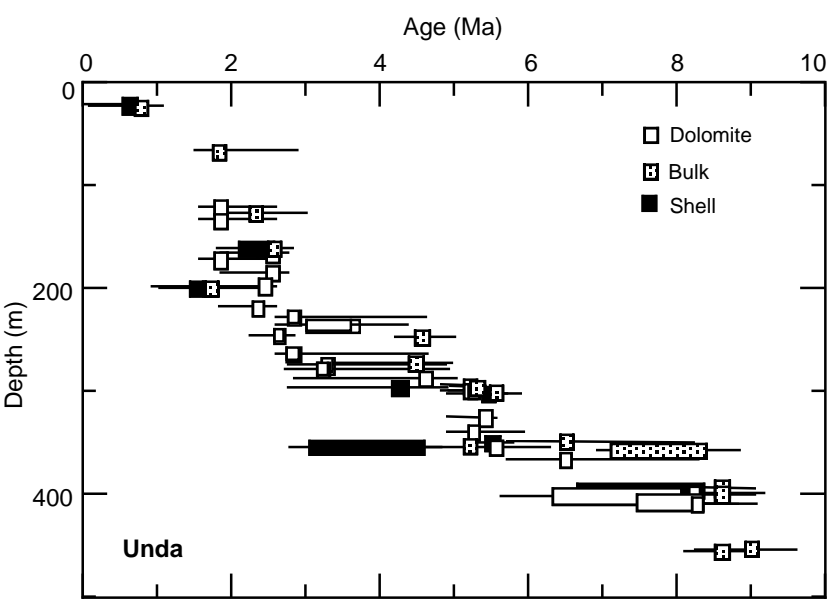

Figure 8. Ages determined from the Sr-isotopic data presented by (Swart et al. (in press, a) for Unda. Error bars represent uncertainty as determined from the $\mathrm{Sr}$-isotope curve.

Ma) of a phosphatic seafloor crust at the base of this interval also supports the correlation. The magnetostratigraphy suggests a hiatus at the base of the section of about $1 \mathrm{~m} . \mathrm{y}$. in duration, whereas the biostratigraphy indicates a slightly longer duration (1.2 m.y.).

Section 3 (521.8 to $367.0 \mathrm{~m})$. Late-early Pliocene, early-late Pliocene. This interval consists of mainly reversed polarity with a normal polarity interval toward the top portion. It is correlated with the reversed portion of the latest Gilbert (C2Ar), the earliest portion of the Gauss Chron, reversed and normal polarity within the middle of Gauss Chron C2An, and perhaps the base of reversed polarity of the Matuyama Chron, respectively. Biostratigraphically the section is constrained by several lower Pliocene markers (see Figs. 6, 9). Above the polarity reversal at $424.6 \mathrm{~m}$, several foraminifer datums suggest that the upper portion of the section is upper Pliocene. Magnetostratigraphically, the upper part of the interval is thus assigned to the early part of the late Pliocene (upper Gauss Chron).

Section 4 (367.0 to $21.9 \mathrm{~m}$ ). Late Pliocene-Holocene. The uppermost interval in Clino consists of a prograding sequence capped by margin, reef, and platform facies. The lower $221 \mathrm{~m}$ has a reversed polarity that is correlated to the lower portion of the Matuyama Chron (Fig. 9). The normal polarity between 146.0 and $125.9 \mathrm{~m}$ is correlated to the Olduvai Subchron. The former correlation is based primarily on the LO of Globorotalia exilis (2.1 Ma, no. 36 in Fig. 9) and the FO of Globorotalia truncatulinoides (1.9 Ma, no. 34 on Fig. 9). Additional foraminifers data support a Matuyama (C2r) age and do not support a Pleistocene age, as suggested in interpretation "a" of Lidz and Bralower (1994). Strontium-isotope ratios on shell material and bulk rock fall consistently on, or just younger than, the age/depth curves based on this interpretation.

\section{Core Unda}

Distinct zones of magnetic polarity were also present in core Unda. The upper portion of the core between 19.5 and $110.6 \mathrm{~m}$ had predominantly normal polarity, punctuated by several reversed polarity intervals. Inclination values in Unda are more variable than in Clino. This scatter in inclination angles may be a result of more shallow-water sediment facies than in Clino, as shallow-water carbonates are known to have highly variable inclinations (McNeill and Kirschvink, 1993).

Section 1 (452.7 to $300.2 \mathrm{~m}$ ). Late Miocene. The bottom part of core Unda is tentatively correlated to early late Miocene Chron C5n through late Miocene Chron C3An. The biostratigraphic markers 


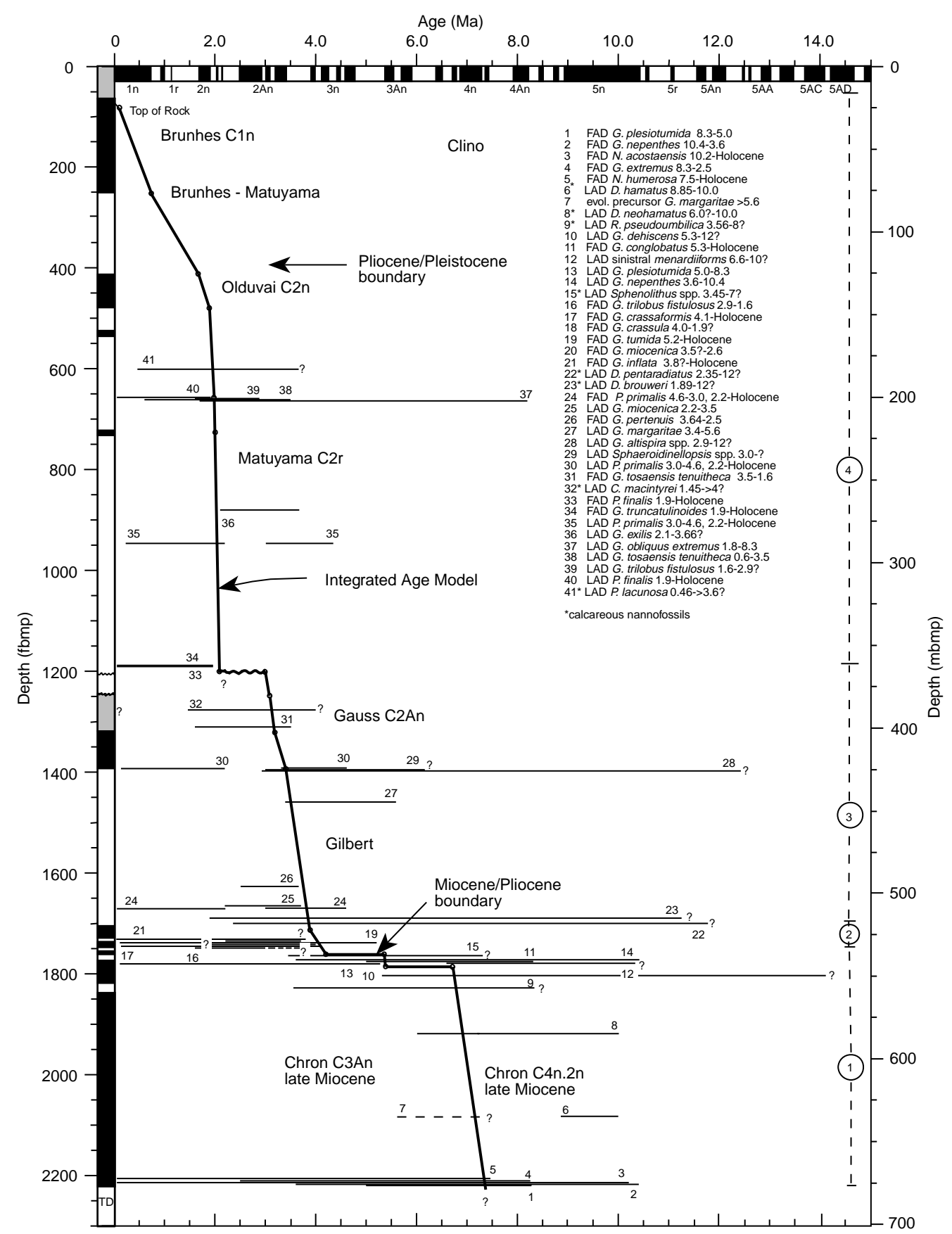

Figure 9. Chronostratigraphic age model Clino (McNeill et al., in press). Circled numbers indicate magnetostratigraphic sections. fbmp = feet below mud pit; mbmp $=$ meters below mud pit.

provide some general constraints and provide a maximum possible age of about 12.6 Ma near the base of the core (Fig. 10). The occurrence of Polyperibola christiani between 368.5 and $357.8 \mathrm{~m}$ indicates a N15-N16 age (Berggren, 1993), between approximately 10.2 and 7.1 Ma. This N15-N16 marker is consistent with a missing or greatly condensed upper Miocene. Thus, based on the assumption that the normal polarity at the base of Unda is Chronozone C 5 n and the N12 foraminifers markers are reworked, the age at the base of section 1 would be either N15 or lower N16, approximately 10.2 to $8.9 \mathrm{Ma}$.

Near the exposure disconformity at $292.6 \mathrm{~m}$, shell, bulk-rock, and dolomite samples had strontium-isotope ages between about 5.5 and 4.5 Ma (Fig. 7). These ages, combined with the biostratigraphic da- tums and phosphate age below (6.0-5.0 Ma at $354.5 \mathrm{~m})$, support a $\mathrm{C} 3 \mathrm{An}$ age correlation. The reversed polarity near $320.0 \mathrm{~m}$ may correlate to the polarity reversal (C3An.1r, 5.68-5.53 Ma) that occurs near the middle of Chronozone C3An.

Section 2 (300.2 to $196.6 \mathrm{~m})$. Early Pliocene to early-late Pliocene. Section 2 consists of two reversed polarity and two normal polarity intervals that are correlated to the Gilbert and Gauss Chrons (Fig. 10). The Gilbert Chronozone consists of reversed polarity from $300.2 \mathrm{~m}$ to $278.3 \mathrm{~m}$ (Chron C3r; 5.35 to $4.77 \mathrm{Ma}$ ). This magnetostratigraphic interpretation by several foraminifers and nannofossil markers (Fig. 10), and a strontium-isotope age on a marine hardground phosphatic crust at $270.4 \mathrm{~m}$ that ranges between 5.0 and 3.5 


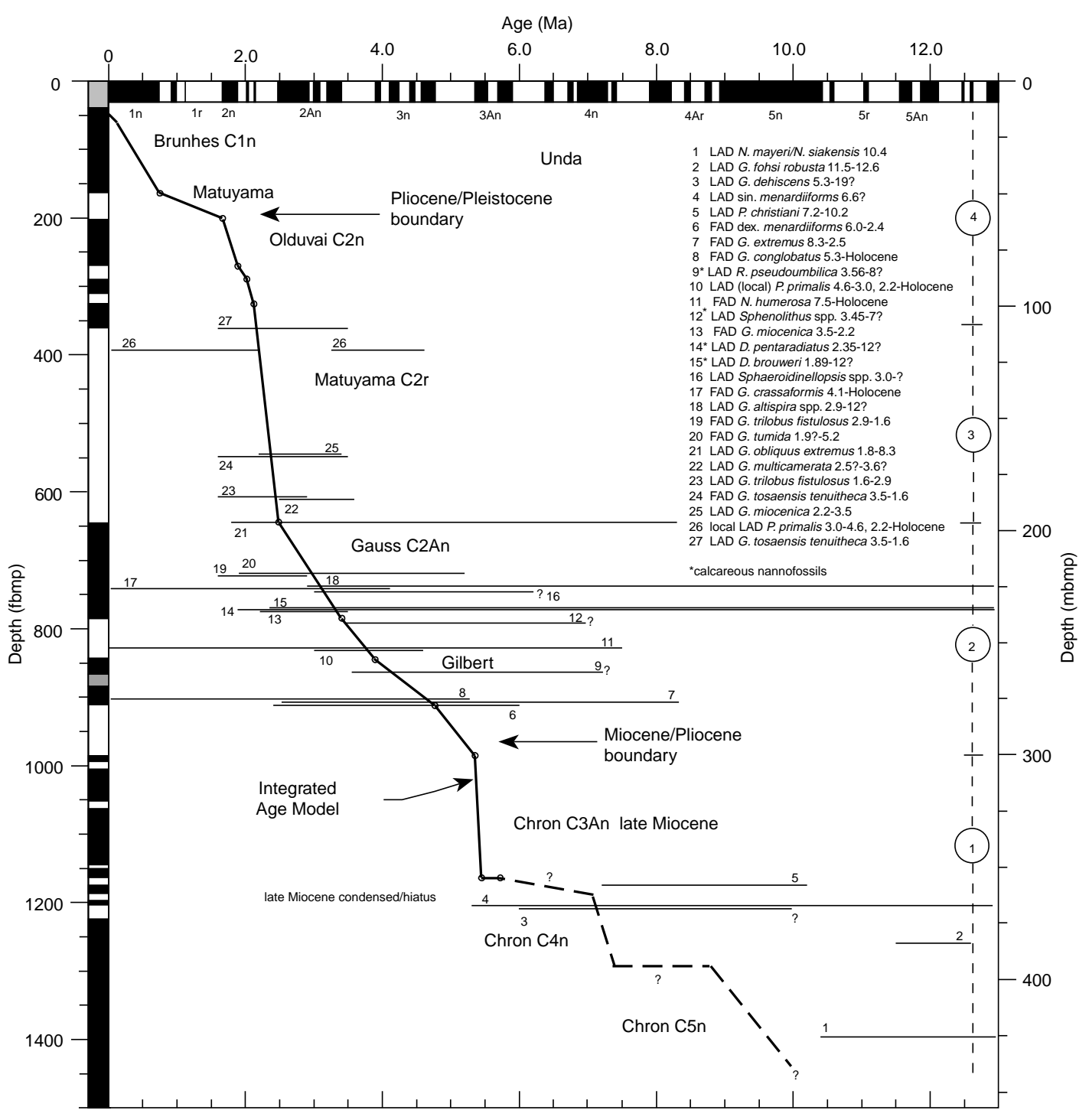

Figure 10. Chronostratigraphic age model Unda (McNeill et al., in press). Circled numbers indicate magnetostratigraphic sections. fbmp = feet below mud pit; mbmp $=$ meters below mud pit.

Ma, indicating a correlation to the upper part of Chron C3n and likely a substantial hiatus at that depth.

Section 3 (196.6 to $108.5 \mathrm{~m}$ ). Late Pliocene. Section 3 consists solely of reversed polarity and is correlated to the early part (C2r) of the Matuyama Chron (Fig. 10) based on the correlation of biostratigraphy and strontium-isotope stratigraphy.

Section 4 (108.5 to $19.5 \mathrm{~m}$ ). Latest Pliocene-Holocene. The upper portion of core Unda, consisting of both reversed and normal polarity zones, is correlated to the late part of Chron C2r encompassing the Reunion Subchrons and the Olduvai Subchron, Matuyama Chron C1r, and the Brunhes C1n Chron (Fig. 10). Shallow-water carbonate sedimentation in the section precludes the use of microfossil biostratigraphy to provide age tie points. The proposed correlation hinges on two strontium-isotope age ranges: (1) a bulk-rock sample at $64.5 \mathrm{~m}$ with an age of 2.5 to $1.0 \mathrm{Ma}$, which would make the normal polarity zone at 82.0 to $61.6 \mathrm{~m}$ correlative to the Olduvai Subchron (1.88 to $1.66 \mathrm{Ma}$ ); and (2) shell and bulk-rock samples at $21.7 \mathrm{~m}$ with age ranges of $0.9 \mathrm{Ma}$ to present and 1.1 Ma to present, respectively. Normal polarity at core depth of the two strontium-isotope samples mentioned above indicates a Brunhes age correlation.

\section{Petrology and Mineralogy}

The carbonates recovered from Unda and Clino display a wide range of textures ranging from largely unaltered carbonates to texturally mature limestones and dolostones. For a detailed description, the reader is referred to Melim et al. (in press). Although both cores are dominated by LMC, there are significant variations in the amounts of aragonite and dolomite throughout both cores.

Based on mineralogy, Unda can be separated into four zones (Fig. 11). The upper zone, corresponding to the upper platform to reefal unit, extends from the top of the recovered interval to $108.1 \mathrm{~m}$ and is composed mainly of LMC with only a trace amount of aragonite. The second interval (108.1-235 m) lies between two reefal units and consists of fine- to coarse-grained skeletal to mixed skeletal-nonskeletal sands and is also principally LMC, but on average contains between $5 \%$ and $10 \%$ aragonite and $10 \%-15 \%$ dolomite. The third zone includes most of the middle platform/reef section and is composed mainly of dolomite. The lower zone consisting of mixed skeletal/peloidal silts and sands and extending from $354.8 \mathrm{~m}$ to the base of the core is mainly LMC with minor $(0 \%-10 \%)$ amounts of dolomite. 


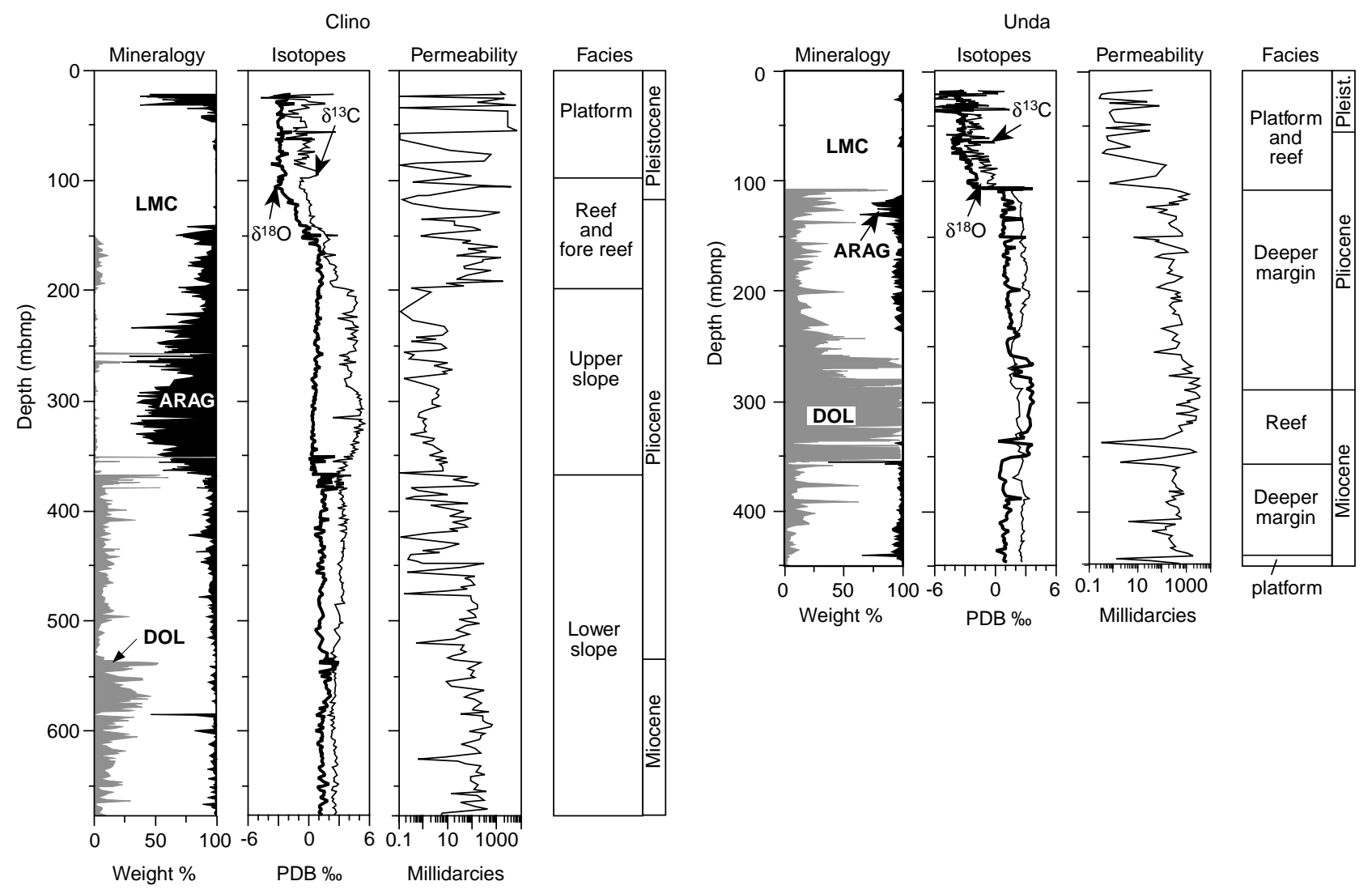

Figure 11. Mineralogical, stable isotopic, and permeability data from Unda and Clino (from Melim et al., 1995).

Clino also contains major variations in mineralogy, the most significant of which is a large increase in aragonite, reaching up to $65 \%$ between 229 and $376 \mathrm{~m}$. Dolomite is important throughout with the exception of the upper $135 \mathrm{~m}$ of the core, the maximum concentrations occurring slightly below hardground surfaces at 367 and $536 \mathrm{~m}$.

Cements: Nonluminescent calcite cements (micrite, isopachous spar, and dogtooth spar) are minor, but nevertheless ubiquitous throughout the core. Cements usually form less than $5 \%$ in both cores. Spar is particularly abundant in the upper $100 \mathrm{~m}$. Intergranular cements are common in grainstones and packstones, whereas intragranular types form in wackestones, packstones, and grainstones. Syntaxial overgrowths are ubiquitous throughout, being found on a variety of grains including echinoderms, foraminifers, and mollusks.

Mineral alteration: Fossil fragments, particularly Halimeda, coral bioclasts and mollusks are commonly neomorphosed. In other instances fragments have been selectively dissolved to form moldic porosity or large vugs. In the upper platform and reef facies of both holes, dissolution features was accompanied by blocky spar with isotopically depleted $\mathrm{C}$ and $\mathrm{O}$ isotopic values. Dissolution of calcitic bioclastics was rare except in dolomitized intervals. Dolomite was present throughout most of the core with the exception of the upper 100-150 m. Four textural types of dolomite have been identified. These include: (1) a fabric-preserving dolomite similar to that described by Dawans and Swart (1988) forming exclusively in skeletal grainstone and packstone lithologies; (2) fine isolated dolomite rhombs ( 1 to $40 \mu \mathrm{m}$ ) ubiquitous throughout the deeper water facies which appear to be primarily a void filling phase; (3) a microsucrosic dolomite replacing up to $50 \%$ of the sediment; (4) finally a micritic dolomite, which occurs as replacement of micritic grains primarily associated with hardgrounds. Minor amounts of celestite occurs as primary precipitates and as replacements of grains below $180 \mathrm{~m}$ in Unda and $360 \mathrm{~m}$ in Clino.
Other features: Numerous lithified surfaces (hardgrounds and firmgrounds) have been identified throughout both cores (Kenter et al., in press). These surfaces typically contain high-magnesium calcite (HMC), dolomite, and phosphate and show abundant evidence of dissolution. In the upper portions of the cores, several exposure surfaces are recognized by the presence of laminated crusts, root casts, recrystallized grains, cements, and reworked clasts. Beneath the exposure surfaces there are often large scale features indicative of dissolution such as vuggy to cavernous porosity that cross cuts bedding and grain boundaries. Selective dissolution of aragonitic bioclasts and peloids was abundant throughout both cores. Skeletal grains were usually completely dissolved, but minor preservation of peloids was common. Although the majority of the aragonite has been dissolved, there are some notable exceptions in Clino between 195 and $367 \mathrm{~m}$, where peloidal grainstones reach over $70 \%$ of the sediment (Figs. 4, 11).

Stable carbon and oxygen isotopic compositions: The oxygen and carbon isotopic compositions of the bulk samples fall into two distinct units. The upper interval, above $108 \mathrm{~m}$ in Unda and $135 \mathrm{~m}$ in Clino exhibits isotopically depleted $\mathrm{C}$ and $\mathrm{O}$ ratios ( $-7.4 \%$ o to $-1.4 \%$ o for $\mathrm{C}$ and $-0.9 \%$ to $-6.5 \%$ o for $\mathrm{O})$. This unit merges into a second zone, characterized by heavier isotopic values throughout the remainder of the core (Fig. 11).

\section{Formation Fluids}

Formation fluids were collected from both holes during drilling and logging, and data were corrected for the effects of surface seawater contamination using tritium (Swart et al., in press, b). Hole Unda was characterized by an upper interval over which the concentration of minor elements did not vary appreciably when compared to seawater (0-150 mbsf) (Fig. 12). Below $150 \mathrm{~m}$, the concentration of stron- 
tium increased from 90 to $262 \mu \mathrm{M}$. When corrected for surface contamination this value increases to $373 \mu \mathrm{M}$. In Clino, values increased to $259 \mu \mathrm{M}$, and to over $700 \mu \mathrm{M}$ when corrected for contamination. Concentrations of $\mathrm{Ca}^{2+}$ showed slight increases, while $\mathrm{Mg}^{2+}$ decreased. The Sr-isotopic ratio of the fluids was more radiogenic than that of the sediments throughout, but when corrected for surface contamination was almost indistinguishable from the host sediment.

\section{Petrophysics}

One of the objectives of the BDP was to determine the cause of seismic reflections in a pure carbonate environment. To achieve this goal, an extensive petrophysical study was undertaken that included the measurements of sonic velocity, density, porosity and permeability. Sonic velocity, density, porosity were measured in the logs and on discrete samples. Compressional and shear-wave velocities were measured under variable confining and pore pressures to simulate burial depth (Anselmetti and Eberli, 1993).

Results from the discrete samples from the upper Miocene and the Pleistocene section of Unda and Clino show a wide range in the compressional wave velocity $\left(V_{p}\right)$ between 1900 and $6400 \mathrm{~m} / \mathrm{s}$. This range is remarkable considering the limited mineralogical variations of carbonates. The effect of carbonate mineralogy is overshadowed by the effects of porosity and pore types. The main factor that controls velocity is porosity. However, we observed a large scatter in the range of velocities within each range of porosity, which is the result of carbonate specific pore types (Anselmetti and Eberli, 1993). The development of individual pore types is directly related to the original sedimentary fabric and later diagenetic alteration. Thus, the velocity is also controlled mainly by (1) the depositional lithology of the carbonate sediment and (2) the diagenetic alterations that affect porosity and pore types. Sonic velocity is much less a function of age or burial depth. In fact, in Unda and Clino, velocity inversions are common. This trend is seen in both the samples measured on discrete samples and on the sonic logs (Fig. 13). This finding is in agreement with observed variable diagenetic alterations downhole and several distinct diagenetic zones. The diagenetic zones that dramatically influence the petrophysical behavior of the rocks seem to follow depositional surfaces and are the reason why seismic reflections also follow depositional surfaces and ultimately allow retrieval of the record of changes in sea level within a sequence stratigraphic framework. The highest impedance contrasts are observed on sequence boundaries and transgressive surfaces, where the combined effect of change in sediment composition and diagenesis is responsible for impedance contrasts and seismic reflections.

\section{DISCUSSION}

\section{Depositional History}

Detailed analyses of the source and mode of accumulation, depositional environments, discontinuity surfaces, sediment composition and foraminifers content of Clino and Unda confirm the concept of highstand shedding as the primary control on the depositional evolution of the Neogene western Great Bahama Bank. The principal source of sediment to the slope is the extensive offbank transport of suspended, fine-grained bank-top "background" sediment during periods of sea-level highstands when the entire platform was submerged providing the bulk, more than $80 \%$, of the slope sediment. During sea-level falls, the supply of fine-grained sediment to the slope environment is reduced or completely stopped. These deposits of reworked margin-derived material form thin intercalations in the "background" sediment. Factors controlling the thickness, composition, and diagenesis of the deposits, and the formation of discontinuity surfaces are (1) the morphology of the platform, hardgrounds may develop at the base (ramp morphology) or at the top of the lowstand deposits (flat-topped platform), (2) the frequency and amplitude of sea-level changes, and (3) the water depth and distance to the margin.

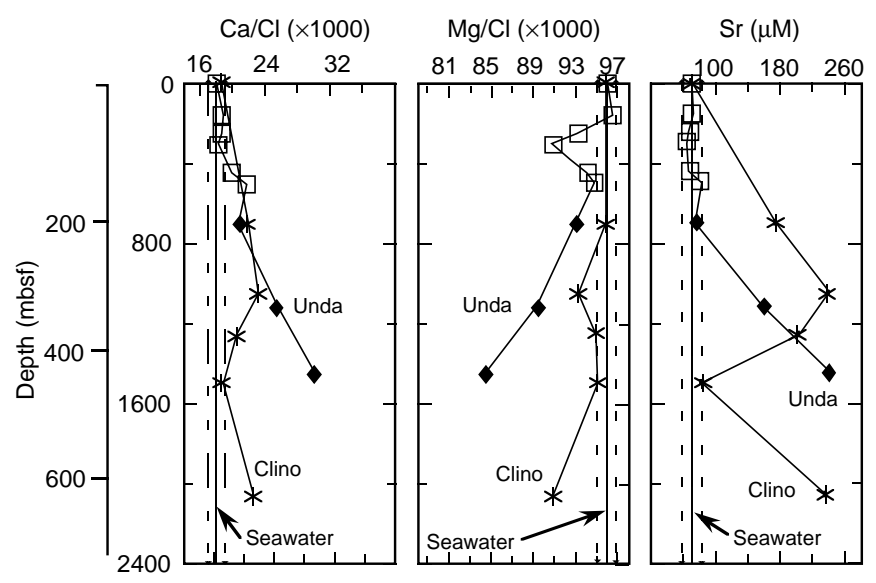

Figure 12. Chemical composition of formation fluids from Unda and Clino (Swart et al., in press, b). In the case of Unda, samples obtained from Hole 1 (open squares) were obtained by pumping during drilling and Hole 4 (solid diamonds) using a bailer after logging. The Clino samples are shown by the stars. The vertical dashed lines represent the approximate analytical uncertainty plotted either side of the normal seawater value for the parameter under consideration.

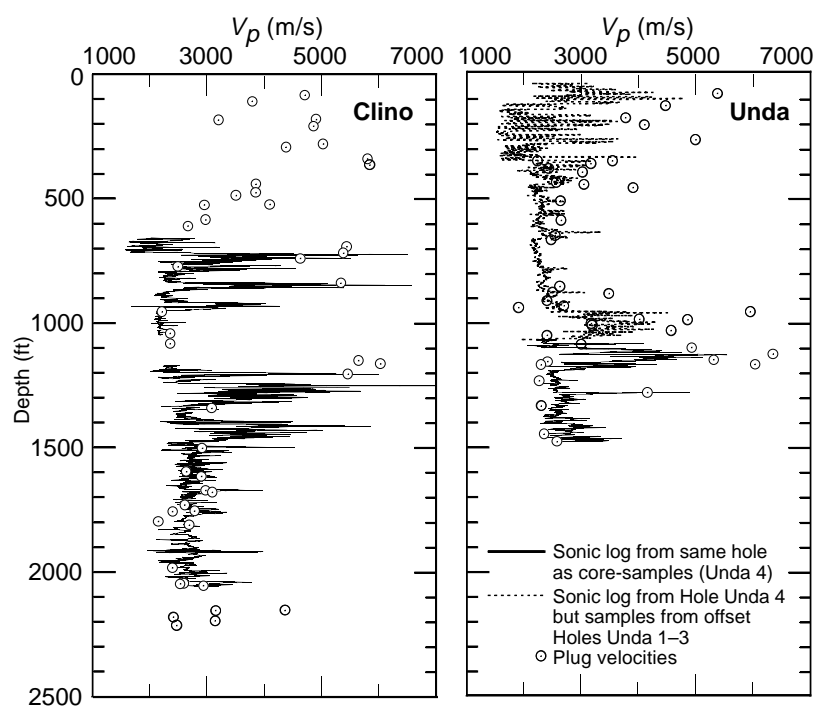

Figure 13. Comparison between ultrasonic lab velocities (circles) and velocities obtained by the sonic wireline $\log$ in the two boreholes on the Great Bahama Bank. Due to the better resolution of the ultrasonic measurements (length of sample $=2-5 \mathrm{~cm}$, compared to the $20-\mathrm{cm} \log$ spacing), lab velocities display usually higher maxima and lower minima. Note the large downhole variation in sonic velocity in these carbonate rocks. The variations are a combined result of original sediment composition and early diagenetic alteration.

\section{Hierarchy of Sea-Level Fluctuations in the Rock Record}

Hole Clino contains a rhythmic alternation of depositional successions that are interpreted as controlled by sea level fluctuations. The bulk of the slope sediment, more than $80 \%$, was sourced by extensive offbank transport of fine-grained, suspended and minor pelagic sediment when the platform was submerged. During sea-level lowstands, only minor amounts of reworked, coralgal sediment were deposited and rapidly cemented on the slope, whereas on the platform and the 
margin, subaerial exposure surfaces developed. During the subsequent initial rise of sea level, marine hardgrounds developed on the slope and, in some cases, at the margin. The marginal coralgal and skeletal shallow-water deposits are reworked. At the same time the margin retreated until sediment production was in equilibrium with sea level and offbank sediment transport of fine-grained sediment resumed (Hine et al., 1981).

In the slope section of GBB, three different frequencies of sealevel fluctuations are recorded as depositional successions, with thickness ranging from meter-scale up to approximately $170 \mathrm{~m}$. Each succession (labelled A-G, Fig. 4) is characterized by distinct variations in composition, texture, and degree of cementation. At the margin, the depositional signature is less distinct and only the largestscale sea-level fluctuations are recognized. Local accumulation and removal by erosion of sediment at the shallow-water margin are suggested to have obscured the sedimentary record of sea-level changes.

\section{Major Depositional Successions (60-170 m)}

Seven larger depositional successions that reflect repetitive cycles in sediment source, mode of accumulation, and diagenesis, were recognized in cores Unda and Clino (60 to $120 \mathrm{~m}$ in thickness at Unda and up to $170 \mathrm{~m}$ at Clino; Fig. 4). Each of these successions has intervals that represent periods of (1) nondeposition or sea-level lowstand, (2) relative deepening, "drowning" or transgressive (flooding) phases, and (3) infill of accommodation space or sea-level highstand. In Clino, succession D (540.0-367.03 m; Fig. 4) has a thin interval of shallow-water derived grains and clasts at the base that is capped by a Fe/Mn-stained marine hardground. The hardground and the overlying interval of planktonic foraminifers packstone, with abundant relatively deeper water species, reflect the rapid transgression that temporarily shut down the supply of shallow-water derived grains. The overlying unit of fine-grained skeletal-peloidal sediment points to the return to a relative highstand of sea-level. Succession C (367.03$197.44 \mathrm{~m}$ ) has an erosional base that is overlain by coarse-skeletal, margin-derived deposits and by peloidal highstand sediments. The underlying succession E (>677.27-540.0 m) is incomplete, but reflects a long period in which there was a relative highstand deposition on the slope.

In Unda, as a result of the shallow-water marginal position of the hole, the successions are not as well pronounced. The base of succession D (292.82-162.5 m) is the erosional unconformity at the top of the middle reefal succession and is capped by deeper water mixed peloidal-skeletal sediment, reflecting a significant drop in sea level followed by rapid flooding causing temporary drowning of the margin at this location. The top of the underlying succession E (360.3$292.82 \mathrm{~m}$ ) has been dolomitized. The transgressive units contain significant amounts of deeper water planktonic foraminifers. The lowstand phase of succession C $(162.5-108.1 \mathrm{~m})$ is represented by the first shoaling deposits of coarse skeletal rubble and is followed by a thick interval of reworked shallow-water sand and rubble with numerous condensed layers that reflect the transgressive phase. The interval of overlying fine-grained skeletal-peloidal sediment is interpreted as the highstand phase. The lower boundary of each succession is associated with a characteristic increase in gamma ray signal and a change in mineralogy.

\section{Medium-Scale (Tens of Meters) Depositional Successions}

At a higher, second level of cyclicity, each larger scale depositional succession of Clino contains three smaller scale successions, tens of meters in thickness. These are interpreted to reflect higher order oscillations that are superimposed on the relative highstand of sea level. In the deeper, and more "distal," portion of Clino, below $367.03 \mathrm{~m}$, these successions consist of very thin, decimeter- to meterscale intervals of margin-derived grains, followed by thick intervals of fine shallow-water derived sediment, representing highstand fa- cies. In the upper part, above $367.03 \mathrm{~m}$, the lowstand deposits have $\mathrm{m}$-scale intervals of coarse margin-derived grains and clasts and are capped by marine hardgrounds that reflect the transgressive phase. In Unda, the coarse-fine alternations represent a similar system of lowstand and subsequent rise in sea level, respectively. At Clino, each succession has an associated change in gamma ray signal; usually an increase near the top of the relative lowstand interval.

\section{Small-Scale (Decimeter to Meter) Depositional Successions}

At a third level of cyclicity, Clino and part of Unda contain meterscale alternations of lithologies that, based on grain composition and intensity of cementation, suggest depositional variations induced by high-frequency oscillations of sea level. In the deeper portion of Clino, below 367.03, and in the finer grained intervals of Unda, alternations of laminated, porous, and cemented wackestones to packstones and grainstones, very similar to those recorded at Clino, record fluctuations in sea level. Here, the effect of sea-level changes is expressed as cycles in grain type and submarine diagenetic overprint (hardground and/or firmgrounds). The cemented layers are interpreted as generated by sea floor lithification during lowstands. The laminated intervals that have more abundant planktonic foraminifers are believed to represent the transgressive phase, whereas the porous layers are highstand deposits.

\section{Sedimentation Rates}

Rates of sediment accumulation associated with clinoform deposition, shelf aggradation, and platform aggradation were constrained using the chronostratigraphic data. Rates of accumulation for prograding pulses were calculated to exceed $300 \mathrm{~m} / \mathrm{m}$.y. In proximal shelf/slope settings, such a rate is not unusual, as accumulation rates in late Pleistocene and Holocene sediments easily reach this value (Wilber et al., 1990). Reef accumulation rates in Unda during the late Miocene were calculated to be as high as $260 \mathrm{~m} / \mathrm{m}$.y. Although well within the accumulation rate of Cenozoic reefs, this high accumulation rate coupled with an actual thickness of $\sim 61 \mathrm{~m}$, suggests that this was a response to rising sea level. Average rates of Pleistocene platform aggradation on western GBB range from around 13 to $84 \mathrm{~m} /$ m.y., and were controlled by whether the highstand elevation was capable of flooding the precursor topography. Overall, the pattern of late Pliocene to late Pleistocene accumulation on western GBB is similar to all other age-dated Bahamian platforms (eastern GBB, LBB, and San Salvador Island), as well as an atoll record in the central Pacific, which strongly suggests eustatic sea-level control. The presence of the rhythmic succession of multiple meter- and decimeter-scale cycles that reflect changes in the source and degree of cementation, also suggests the dominant role of sea level.

The sedimentation at the western margin of GBB could also have been influenced by ocean currents (e.g., the Gulf Stream that influenced the circulation of the North Atlantic in the Neogene). A major effect of bottom currents in the formation of depositional successions is unlikely based on the observation that the planktonic foraminifers sands in Clino overlying the marine hardground at the Miocene/ Pliocene boundary $(536.3 \mathrm{~m})$ do not show any indication of hydrodynamic sorting or winnowing by bottom currents. On the contrary, they have a sorting similar to the underlying and overlying planktonic foraminifers-rich sediment and are muddy. Both variations in sea level and current velocity may, however, be the result of climatic changes and together influence slope deposition.

\section{Correlation Between Cores and Seismic Sections}

A vertical seismic profile and a synthetic seismic profile derived from the sonic and density-logs were used to tie the cores Unda and Clino to the seismic sequences. Several check shots from the VSP 
survey with correct depth-time values were entered into the ITA program. These check shots placed the reflections at correct travel times so that the synthetic seismograms could be compared with the observed seismic line.

Within the resolution of the seismic reflection, all but one of the seismic sequence boundaries correlated with a lithologic facies change (Fig. 4). In addition, several of these facies changes indicate a falling sea level. At the platform interior site Unda, four seismic sequence boundaries, A, B, C, and F, coincide with subaerial exposure horizons that are generally overlain by marine facies. As such, the seismic sequence boundaries image the exposure horizons, but are also flooding surfaces for the subsequent sea-level rise.

Generally these sequences display a regressive trend in their vertical facies assemblages that reflects the flooding and subsequent filling of the accommodation space. For example, the 128.6-m-thick seismic Sequence $c$ in Clino displays a regressive facies succession through a reefal unit. The base of this sequence falls near the base of a fore-reef deposits that are overlain by a nearly $50 \mathrm{~m}$ thick reefal unit. The reef itself is capped by platform interior sediments. In the overlying Sequences $a$ and $b$, the facies consist of flat-lying platform interior facies. In these facies high-frequency sea-level changes are documented by several exposure horizons. The seismic sequence boundaries coincide with intervals where these exposure horizons are closely spaced. Within the slope sections, the inferred positions of the seismic sequence boundaries coincide with hardgrounds and/or intervals with increased pelagic components. These intervals also contain fine, redeposited lithoclasts from the bank margin that are partially blackened. These blackened grains give these intervals a "salt-andpepper" appearance. Two sequence boundaries, D in Unda and E in Clino, fall into zones of more gradual facies changes.

\section{Ages of Sequence Boundaries and Sequences}

Seismic sequence boundaries (SSB) were identified in multichannel seismic lines before drilling, and refined after coring and welllogging. The ages of seismic reflections forming sequence boundaries are summarized below and in Table 1.

Sequence $a, b$. These two youngest sequences are late Pleistocene in age. SSBs A and B show nearly horizontal deposition of platformtop facies during the Brunhes Chron. Consequently, the seismic reflections are also near horizontal. SSB A, which is delineated near Clino and farther west, however, merges with the reflection representing SSB B before reaching Unda, indicating some topography. No additional age constraints could be placed on these sequence boundaries.

Sequence c. SSB C is placed near the base of the Olduvai Subchron zone in the upper Pliocene, that is, in sediments of approximately 2.1 Ma. In both holes Unda and Clino, the boundary occurs at the base of the reef facies. The reef started to grow sometime between 2.0 and 1.9 Ma and continued at Unda until the end of the Olduvai $(\sim 1.66 \mathrm{Ma})$. At Clino, reef growth continued well into the Matuyama Chron (1.66-0.87 Ma), further reducing topographic relief between the two boreholes.
Sequence $d$. Sequence $d$ is upper Pliocene and lasted from $\sim 2.5$ Ma to $2.1 \mathrm{Ma}$. This interpretation is based on the following data. In Unda the base of the sequence is placed at $131 \mathrm{~m}$ in zone of reversed polarity interpreted as being the early part of the Matuyama Chron (C2r). Toward Clino the correlative reflector dips to a depth of 379.3 $\mathrm{m}$ and the seismic sequence boundary is correlated to the erosional horizon at $367 \mathrm{~m}$. Below the seismic sequence boundary, the normal polarity zone, that is, the Gauss polarity, is relatively thin and incomplete, indicating a significant erosion on this outer shelf setting during the formation of the boundary. The short duration of the subsequent accumulation of the sequence between 2.5 and 2.1 Ma, gives evidence for extremely rapid sedimentation and lateral progradation of the platform.

Sequence e. Sequence $e$ is lower upper Pliocene in age, 3.5 Ma2.5 Ma. The basal SSB E coincides with the early/late Pliocene boundary. Lithologically it is marked in Clino by an interval of pelagic-rich sediments in the slope section. In Unda the boundary coincides with a firmground in fine skeletal slope sediments.

Sequence $f$. Sequence $f$ is early Pliocene in age, $4.8-3.5$ Ma. In Unda and in Clino the base of the sequence overlies a hardground at $292.8 \mathrm{~m}$ and $536.3 \mathrm{~m}$, respectively. SSB F is well constrained in age between the top of Chronozone C3An and the base of Chronozone C3n (5.3-4.7 Ma). The C3An to C3n interval contains the Miocene/ Pliocene boundary. In Clino the chronostratigraphy indicates a hiatus of approximately $1.2 \mathrm{~m}$.y. Seismically the basal portion of the sequence is a transgressive system with a major backstepping of the margin. The subsequent progradation in the late early Pliocene and early late Pliocene was marked by high rates of accumulation and shelf/slope progradation at both Unda and Clino.

Sequence $g$. Sequence $g$ is Messinian in age but is only recovered in Unda. At Clino the sequence is reduced into condensed section underlying the hardground. In Unda, the sequence consists of a reefal unit with little biostratigraphic information. Strontium data indicate a late Miocene age for Sequence $g$ and an age somewhat older than the slope sequence. SSB G coincides in Unda ( $449.6 \mathrm{~m}$ ) with a phosphatic surface at the base of the middle reefal unit, and in Clino with the base of a condensed zone $(544 \mathrm{~m})$ that is capped by a phosphatic hardground. In this hardground-topped section SSBs F and G merge seismically.

Sequence $h$. Sequence $h$ is probably upper Miocene, ranging from 2-6.5 Ma based on Sr-isotope stratigraphy. Foraminifers in this sequence suggest an older age (upper N12-N16 Zone), but Lidz and McNeill (1995a) demonstrated that these foraminifers are reworked. The section has mostly normal magnetic polarity. This normal polarity zone is correlated with magnetic Chron C $5 \mathrm{n}$. The lower seismic sequence boundary is positioned near the contact between the lower platform margin deposits and overlying sediments of the shelf facies.

Age constraints across the western margin of GBB indicate that the seismic reflection horizons that constitute seismic sequence boundaries are synchronous, within the age resolution (Fig. 14). Especially well constrained is the upper Miocene sequence Boundary $\mathrm{G}$, the upper Pliocene sequence Boundary D, and a Pliocene/Pleistocene sequence Boundary B. The upper Miocene and upper Pliocene

Table 1. Ages of seismic sequence boundaries.

\begin{tabular}{|c|c|c|c|c|c|}
\hline \multirow{2}{*}{$\begin{array}{l}\text { Sequence } \\
\text { boundary }\end{array}$} & \multicolumn{2}{|c|}{ Sequence } & \multicolumn{2}{|c|}{ Depth (m/ft bmp) } & \multirow{2}{*}{$\begin{array}{l}\text { Estimated age range of } \\
\text { seismic sequence boundary }\end{array}$} \\
\hline & Unda & Clino & Unda & Clino & \\
\hline SSB A & NP & $a / b$ & NP & $21.3 / 70$ & late Pleistocene $<0.83 \mathrm{Ma}$ \\
\hline SSB B & $a-b / c$ & $b / c$ & $30.5 / 100$ & $33.5 / 110$ & late Pleistocene $<0.83 \mathrm{Ma}$ \\
\hline SSB C & $c / d$ & $c / d$ & $102.4 / 336$ & $162.1 / 532$ & late Pliocene $\sim 2.1 \mathrm{Ma}$ \\
\hline SSB D & $d / e$ & $d / e$ & $131.0 / 430$ & $367.0 / 1204$ & late Pliocene $\sim 2.5-2.1 \mathrm{Ma}$ \\
\hline SSB E & elf & $e / f$ & $249.0 / 817$ & $449.6 / 1475_{*}$ & early Pliocene $\sim 3.5 \mathrm{Ma}$ \\
\hline SSB F & f/g & f/g & $292.6 / 960$ & $544.4 / 1786_{*}^{*}$ & early Pliocene $\sim 4.8-3.9 \mathrm{Ma}$ \\
\hline SSB G & $g / h$ & $g / h$ & $354.5 / 1163$ & $544.4 / 1786$ & late Mio. (Messinian) $5.5-4.8 \mathrm{Ma}$ \\
\hline SSB H & $h / i$ & ND & $441.0 / 1447$ & ND & late Mio. (base Tortonian) 8.9-10.4? Ma \\
\hline
\end{tabular}

Notes: * = sequence Boundaries $\mathrm{F}$ and $\mathrm{G}$ merge. $\mathrm{NP}=$ not present $\mathrm{ND}=$ not drilled. 


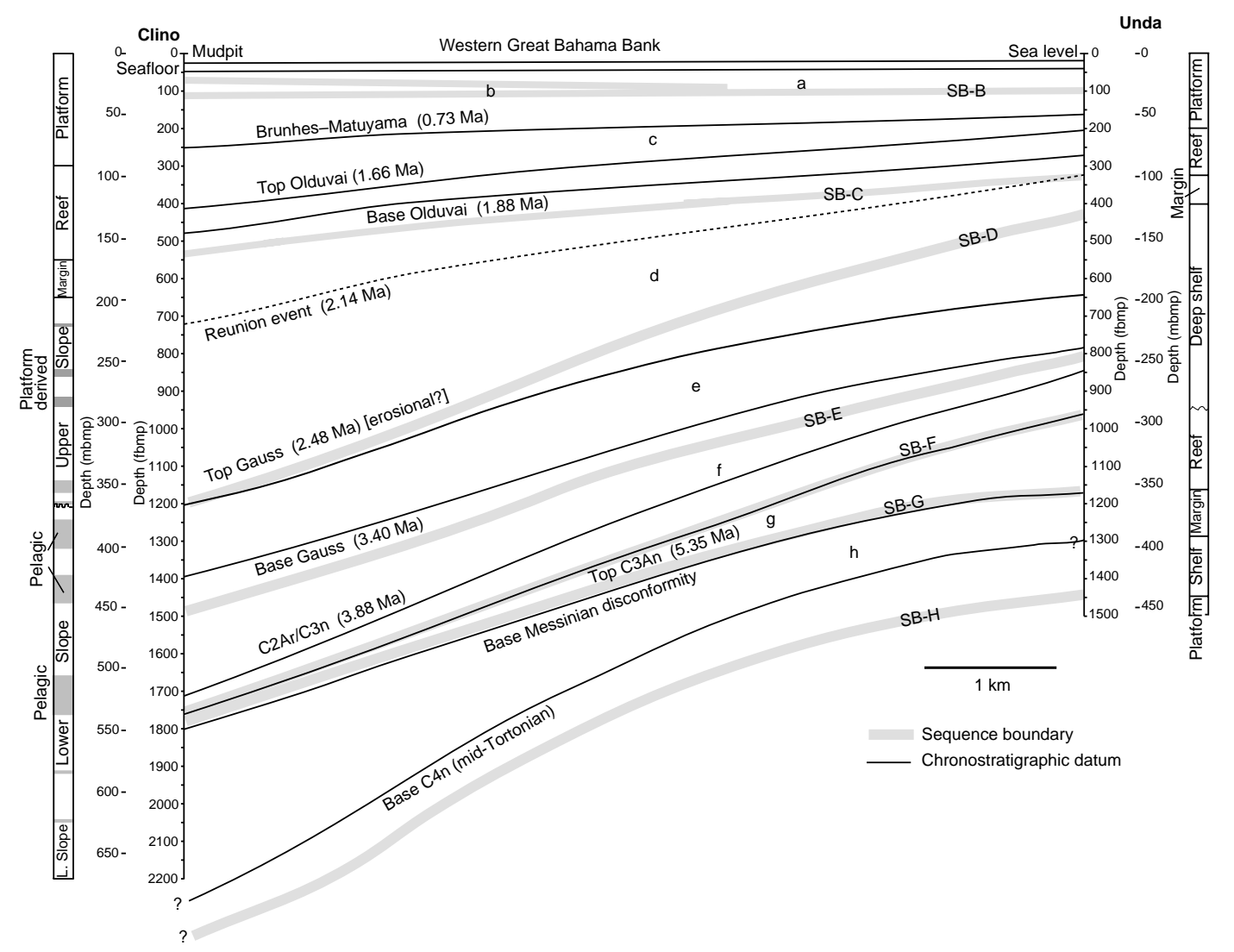

Figure 14. Comparison of chronostratigraphic time lines and seismic sequence boundaries between the two boreholes Unda and Clino. Seismic sequence boundaries do not cross time lines and are synchronous between the two holes, indicating that seismic reflection horizons are time lines. fbmp $=$ feet below mud pit; mbmp $=$ meters below mud pit.

sequence boundaries both represent periods of erosion and/or nondeposition on the slope, and can be tied to major changes in sea level.

\section{Summary of Sea-Level History from the Sedimentary and Seismic Record in Unda and Clino}

The availability of a high-resolution chronostratigraphy enables the development of well-constrained platform evolution and sea-level records. The oldest sea-level event recorded was a latest middle or earliest late Miocene ( $<12.6 \mathrm{Ma}$ ) highstand event that flooded an existing shallow platform and resulted in slope/open-shelf facies near Unda. This highstand flooding gave way to a prolonged upper middle Miocene condensed interval, capped by shallow-water facies and a distinct discontinuity surface. A subsequent late Miocene event deposited shallow-water reefal sediment near Unda. The early Pliocene consisted of a major sea-level rise that forced eastward backstepping of the shallow-water platform. The subsequent highstand resulted in major progradation of the western margin of GBB. The late Pliocene again saw progradation of the margin and the westward shift of the clinoform depocenter. This late Pliocene highstand event was interrupted by a fall in sea level, temporarily reducing sediment production on the platform and resulting in a marine hardground on the proximal slope. At Clino, deposition of a pelagic-rich unit occurred during this drop in sea level, followed by extremely high sedimentation related to the westward shift of the upper-shelf zone of sediment production. This lowstand is correlative to the buildup of Northern Hemisphere glaciers and the worldwide drop in eustatic sea level. The late Pliocene/Pleistocene lowstand is consistently recorded in
Bahamian platforms as well as around the world. The numerous subaerial-exposure horizons in the upper portion of both Unda and Clino provide a record of the frequent middle and late Pleistocene highstand flooding events.

Three major progradational episodes were delineated using seismic stratigraphy, lithostratigraphy, and depositional age information. Progradation occurred during the late Miocene, late early Pliocene, and latest Pliocene, a time period considered a "lowstand" on much of the shallow platform. In the Pliocene shelf/ramp setting, margin progradation initiated during the highstand, but also occurred in a forced regression-type situation during a fall in sea level. Rapid reef progradation occurred near the end of the Pliocene and early Pleistocene when the platform had infilled the proximal slope sufficiently to provide a near horizontal migration surface. The transformation from a shelf/ramp platform topography to a horizontal-top platform started during the late Pliocene and culminated in the middle Pleistocene. As a result, the distinction between highstand and lowstand was much less distinct during much of the late Cenozoic as GBB had a gently dipping shelf/ramp morphology. The steep platform margin and associated abrupt on/off nature of sea-level highstand/lowstand seen today, and through much of the middle and late Pleistocene, are fairly recent developments.

\section{Diagenesis}

Based on a consideration of the differing diagenetic fabrics, a paragenetic sequence has been developed (Melim et al, in press; see Fig. 15). The various different diagenetic elements within this paragenetic sequence are discussed in the following section. 


\section{Diagenesis Related to Hardgrounds and Subaerial Surfaces}

There are numerous nondepositional and erosional surfaces in both Clino and Unda. The subaerially exposed surfaces are common in the upper $150 \mathrm{~m}$ of Clino and Unda, but are absent below this depth in Clino and rare in Unda. Such surfaces are readily identified by petrologic characteristics (blackened pebbles, rootlets, laminated surfaces etc.) and geochemical parameters such as trace elements and stable carbon and oxygen isotopes. Typically such surfaces have high trace element concentrations as a result of input from atmospheric dust (Rossinsky et al., 1992), and depleted carbon and oxygen isotopic values (Allan and Matthews, 1982). In both cores below $150 \mathrm{~m}$, there are abundant marine nondepositional surfaces. These are characterized by the effects of boring organisms and high concentrations of dolomite at or slightly below the surface. In some instances, these surfaces show a slight depletion in the carbon isotopic values indicating input from remineralized organic material. These surfaces clearly formed early although they could also slightly post date other diagenetic features such a marine cementation and even the deposition of calcite spar. Cementation by other marine and freshwater cements can take place while the sediment is being deposited or during exposure and periods of nondeposition.

Marine diagenesis. Based on the distinct change in the carbon and oxygen isotopic composition between 150 and $200 \mathrm{mbmp}$ in both Clino and Unda, it is certain that the lower portion of Clino and the majority of Unda have never been significantly altered in a meteoric fluid (Fig. 11). Above $150 \mathrm{~m}$ the rocks all contain isotopically light carbon and oxygen values, while below this depth the values are heavy and suggestive of marine conditions. Despite these significant differences in the $\mathrm{C}$ and $\mathrm{O}$ isotopic composition, there are intervals that contain neomorphic grains and/or equant calcite cemented intervals believed to be formed in both marine and freshwater dominated intervals that previously had been thought to be indicative of alteration solely in freshwater settings. The timing of the freshwater alteration was early when compared to the marine cementation, which could have taken place at any time from immediately after deposition to the present day. It is proposed that the driving mechanism for the diagenesis is the alteration of organic material either indigenous to the sediments or brought into the section by the movement of fluids. Sulfate from seawater causes the oxidation of the organic material lowering $\mathrm{pH}$ and dissolving biogenic, less-stable forms of calcium carbonate and precipitating calcite and aragonite.

Aragonite preservation. An interesting feature of Clino is the presence of relatively large amounts of aragonite between 150 and $350 \mathrm{mbsf}$ (Fig. 11). We believe that the preservation of aragonite is related to the original peloidal nature of the platform derived grains. These grains deformed after deposition and formed a relatively tight fabric with low permeability. Diagenetic fluids were therefore prevented from passing through this zone and altering it to LMC and dolomite. Instead what cementation has taken place in this interval has derived its source of carbonate from a local supply which resulted in cementation. This rock was later fractured and the precipitation of celestite occurred in some of the fracture voids.

Dolomitization. Considering the wide distribution and variety of dolomite present in the cores, it appears that more than one dolomitization event occurred. The hardground dolomites were clearly formed during the nondepositional phase and were therefore early. This is supported by the distribution of dolomite relative to the hardgrounds and various geochemical information including Sr concentrations and carbon and oxygen stable isotopes. The micritic to fine rhombic dolomite is similar to dolomite commonly found in deep-sea cores. The timing of its formation is unknown, although the similarity of its $\mathrm{Sr}$-isotopic composition to the surrounding sediment may indicate an origin contemporaneous to the deposition of the original sediment. The main dolomitization event in Unda is more difficult to interpret. The mechanism of dolomitization was clearly one which allowed a more pervasive and massive alteration. The Sr-isotopic composition again suggests a timing of formation close to the depositional age, and in this case dolomite formation may have been related to fluid flow associated with the seawater flow below a freshwater-seawater interface.

Celestite formation. The formation of celestite in fractures in certain intervals at Clino is clearly one of the later diagenetic event post-

\begin{tabular}{|c|c|c|c|}
\hline Element & Meteoric & Early marine & Marine burial \\
\hline \multicolumn{4}{|c|}{ Caliche crusts } \\
\hline \multicolumn{4}{|c|}{ Blocky calcite spar } \\
\hline \multicolumn{4}{|c|}{ Neomorphism } \\
\hline \multicolumn{4}{|l|}{ Dissolution } \\
\hline \multicolumn{4}{|c|}{ Hardgrounds } \\
\hline \multicolumn{4}{|c|}{ Micritic cements } \\
\hline \multicolumn{4}{|c|}{ Isopachous cements } \\
\hline \multicolumn{4}{|c|}{ Overgrowths } \\
\hline \multicolumn{4}{|c|}{ Dogtooth calcite spar } \\
\hline \multicolumn{4}{|c|}{ Micrite $\rightarrow$ Microspar } \\
\hline \multicolumn{4}{|l|}{ Dolomite } \\
\hline \multicolumn{4}{|l|}{ Compaction } \\
\hline \multicolumn{4}{|l|}{ Fracturing } \\
\hline Celestite & & & \\
\hline
\end{tabular}

Figure 15. Paragenetic elements and environments of diagenesis for cores Unda and Clino (Melim et al., in press). 
dating the formation of the fractures themselves. The fluids responsible for this formation were clearly allochthonous and passed through fractures in the cemented sediment.

\section{Fluid Flow}

A third possible mechanism, Kohout convection, involved the circulation of cold water, buoyed upward by the higher heat gradient within the platform compared to the adjacent oceans, through the flanks of the platform. This process was first described by Kohout $(1965 ; 1967)$ in the subsurface of South Florida. Simms (1984) concluded that such a flow should be present in all steep-margined platforms where there is a strong horizontal pore-water density gradient. The recharge of water for this process would take place at some depth on the flanks of the platform. At the time of drilling there was insufficient information to distinguish between the different mechanisms.

\section{SUMMARY}

The cores Clino and Unda represent some of the first attempts to obtain rock and fluid samples from deep within a modern carbonate platform. Combined with excellent seismic line, the following important results have been obtained:

1. Using a combination of excellent core recovery and a VSP, the seismic sequence boundaries have been tied to the core material.

2. The facies successions in the recovered cores support the interpretation that the seismic sequences were sea-level controlled.

3. The sequence boundaries have been age dated using a combined chronostratigraphic approach.

4. The ages of the sequence boundaries are synchronous between Unda and Clino confirming that seismic reflections follow time lines and have a chronostratigraphic significance.

5. Petrophysical investigations show that the necessary impedance contrast to create sequence boundaries was created by a combination of sediment composition and early diagenesis along depositional surfaces.

6. Pervasive alteration or the original carbonate sediments has been identified occurring in a mainly marine environment.

7. Combining geochemical analyses of fluids with evidence from core samples with strong evidence of fluid flow, has been documented in the subsurface of a carbonate platform.

\section{ACKNOWLEDGMENTS}

The authors would like to thank the many persons who have helped during the course of this project, including Michael Grammer, Sam Mg, Tom Elliot, Mohamed Shabaan, and Volker Vahrenkamp. The project was support by NSF grants OCE-8917295 and 9204294 , DOE grant DE-FG05-92ER14253 and the Industrial Associates Program of the Comparative Sedimentology Laboratory. This manuscript benefitted from reviews by Chris Kendall and Victor Rossinsky.

\section{REFERENCES}

Aïssaoui, D.M., McNeill, D.F., and Kirschvink, J.L., 1990. Magnetostratigraphic dating of shallow-water carbonates from Mururoa atoll, French Polynesia: implications for global eustasy. Earth Planet. Sci. Lett., 97:102-112.

Allan, J.R., and Matthews, R.K., 1982. Isotope signatures associated with early meteoric diagenesis. Sedimentology, 29:797-817.

Anselmetti, F.S., and Eberli, G.P., 1993. Controls on sonic velocity in carbonates. Pure Appl. Geophys., 141:287-323.

Austin, J.A., Jr., Schlager, W., et al., 1988. Proc. ODP, Sci. Results, 101: College Station, TX (Ocean Drilling Program).
Austin, J.A., Jr., Schlager, W., Palmer, A.A., et al., 1986. Proc. ODP, Init. Repts., 101: College Station, TX (Ocean Drilling Program).

Beach, D.K., 1993. Submarine cementation of subsurface Pliocene carbonates from the interior of Great Bahama Bank. J. Sediment. Petrol., 63:1059-1069.

Beach, D.K., and Ginsburg, R.N., 1980. Facies succession, Plio-Pleistocene carbonates, Northwestern Great Bahama Bank. AAPG Bull., 64:16341642.

Beets, C.J., 1992. Calibration of Late Cenozoic marine strontium isotope variations and its chronostratigraphic and geochemical applications [Ph.D. dissert.]. Vrije Univ., Amsterdam.

Berggren, W.A., 1993. Neogene planktonic foraminifers biostratigraphy of eastern Jamaica. In Wright, R.M., and Robinson, E. (Eds.), Biostratigraphy of Jamaica. Mem.-Geol. Soc. Am., 182:179-217.

Berggren, W.A., Kent, D.V., Flynn, J.J., and van Couvering, J.A., 1985. Cenozoic geochronology. Geol. Soc. Am. Bull., 96:1407-1418.

Budd, A.F., and Kievman, C.M., in press. Coral assemblages and reef environments in the Bahamas Drilling Project Cores. In Ginsburg, R.N. (Ed.), SEPM Contributions in Sedimentology.

Christie-Blick, N., Mountain, G.S., and Miller, K.G., 1990. Stratigraphic and seismic stratigraphic record of sea-level change. In Sea-level Change: Washington (National Academy Press), 116-140.

Dawans, J.M., and Swart, P.K., 1988. Textural and geochemical alternations in late Cenozoic Bahamian dolomites, Sedimentology, 35:385-403.

DePaolo, D.J., 1986. Detailed record of the Neogene Sr isotopic evolution of seawater from DSDP Site 590B. Geology, 14:103-106.

DePaolo, D.J., and Ingram, B.L., 1985. High-resolution stratigraphy with strontium isotopes. Science, 227:938-941.

Eberli, G., and Ginsburg, R.N., 1987. Segmentation and coalescence of platforms, Tertiary, NW Great Bahama Bank. Geology, 15:75-79.

Eberli, G.P., and Ginsburg, R.N., 1989. Cenozoic progradation of NW Great Bahama Bank: a record of lateral platform growth and sea fluctuations. In Crevello, P.D., et al. (Eds.), Controls on Carbonate Platform and Basin Evolution. Spec. Publ.-Soc. Econ. Paleontol. Mineral., 44:339355.

Farrell, J.W., Clemens, S.C., and Gromet, L.P., 1995. Improved chronostratigraphic reference curve of late Neogene seawater ${ }^{87} \mathrm{Sr} /{ }^{86} \mathrm{Sr}$. Geology, 23:403-406.

Field, R., and Hess, H., 1933. A borehole in the Bahamas. Ann. Meet. AGU, 234-235.

Fritz, P., and Jackson, S., 1971. Geochemical and isotopic characteristics of Middle Devonian dolomites from Pine Point, northern Canada. 24th Int. Geol. Conf., 230-243.

Füchtbauer, H., 1974. Sediments and sedimentary rocks 1, Sedimentary Petrology (Pt. 2): Stuttgart and New York (Schweiz. Verlagsbuch. and Halsted Press)

Gidman, J., 1978. Diagenesis of cored Pleistocene carbonates, Great Abaco Island, Little Bahama Bank [Ph.D. thesis]. Liverpool.

Haq, B.U., Hardenbol, J., and Vail, P.R., 1987. Chronology of fluctuating sea levels since the Triassic. Science, 235:1156-1167.

Hine, A.C., Wilber, R.J., Bane, J.M., Neumann, A.C., and Lorenson, K.R., 1981. Offbank transport of carbonate sands along open, leeward bank margins: northern Bahamas. Mar. Geol., 42:327-348.

Hodell, D.A., Mead, G.A., and Mueller, P.A., 1990. Variation in the strontium isotopic composition of seawater ( 8 Ma to present): implications for chemical weathering rates and dissolved fluxes to the oceans. Chem. Geol. (Isotope Geosci. Sect.), 80:291-307.

Hodell, D.A., Mueller, P.A., and Garrido, J.R., 1991. Variations in the strontium isotopic composition of seawater during the Neogene. Geology, 19:24-27.

Illing, L., 1959. Deposition and diagenesis of some upper Paleozoic carbonate sediments in western Canada. 5th World Petrol. Congr., 23-52.

Kendall, C.G.St.C., and Schlager, W., 1981. Carbonates and relative changes in sea level. In Cita, M.B., and Ryan, W.B.F. (Eds.), Carbonate Platforms of the Passive-type Continental Margins, Present and Past. Mar. Geol., 44:181-212.

Kenter, J.A.M., Ginsburg, R.N., and Treolstra, S.R., in press. The western Great Bahama Bank: sea-level-driven sedimentation patterns on the slope and margin. In Ginsburg, R.N. (Ed.), SEPM Contributions in Sedimentology.

Kohout, F.A., 1965. Submarine springs: a neglected phenomenon of coastal hydrology. Central Treaty Org. Symp. Hydrol. Water Res. Dev., 391-413.

, 1967. Ground-water flow and the geothermal regime of the Floridian Plateau. Trans. Gulf Coast Assoc. Geol. Soc., 17:339-354. 
Lidz, B.H., and Bralower, T.J., 1994. Microfossil biostratigraphy of prograding Neogene platform-margin carbonates, Bahamas: age constraints and alternatives. Mar. Micropaleontol., 23:265-344.

Lidz, B.H., and McNeill, D.F., 1995a. Deep-sea biostratigraphy of prograding platform margins, Neogene, Bahamas: key evidence linked to depositional rhythm. Mar. Micropaleontol., 25:87-125.

, 1995b. Reworked Paleogene to early Neogene planktonic foraminifers: implications of an intriguing distribution at a late Neogene prograding margin, Bahamas. Mar. Micropaleontol., 25:221-268.

Ludwig, K.R., Halley, R.B., Simmons, K.R., and Peterman Z.E., 1988. Strontium-isotope stratigraphy of Enewetak Atoll. Geology, 16:173-177.

Mattes, B.W., and Mountjoy, E.W., 1980. Burial dolomitization of the upper Devonian Miette buildup, Jasper National Park, Alberta. In Zenger, D.H., Dunham, J.B., and Ethington, R.L. (Eds.), Concepts and Models of Dolomitization. Spec. Publ.—Soc. Econ. Paleontol. Mineral., 28:259-297.

McNeill, D.F., Eberli, G.P., Lidz, B.H., Swart, P.K., and Kenter, J.A.M., in press. Chronostratigraphy of prograding carbonate platform margins: a record of dynamic slope sedimentation, Western Great Bahama Bank. In Ginsburg, R.N. (Ed.), SEPM Contributions in Sedimentology.

McNeill, D.F., Ginsburg, R.N., Chang, S.-B.R., and Kirschvink, J.L., 1988. Magnetostratigraphic dating of shallow-water carbonates from San Salvador, Bahamas. Geology, 16:8-12.

McNeill, D.F., and Kirschvink, J.L., 1993. Early dolomitization of platform carbonates and the preservation of magnetic polarity. J. Geophys. Res., 98:7977-7986.

Melim, L.A., Swart, P.K., and Maliva, R.G., 1995. Meteoric-like fabrics forming in marine waters: implications for the use of petrography to identify diagenetic environments. Geology, 23:755-758.

, in press. Meteoric and marine burial diagenesis in the subsurface of great Bahama Bank. In Ginsburg, R.N. (Ed.), SEPM Contributions in Sedimentology.

Newell, N.D., and Rigby, J.K., 1957. Geological studies on the Great Bahama Bank. In Leblanc, R.J., and Breeding, J.G. (Eds.), Regional Aspects of Carbonate Deposition. Spec. Publ.-Soc. Econ. Paleontol. Mineral., 5:15-72.

Pierson, B.J., 1982. Cyclic sedimentation, limestone diagenesis and dolomitization in upper Cenozoic carbonates of the southeastern Bahamas. [Ph.D thesis]. Univ. of Miami.

Rossinsky, V., Jr., Wanless, H., and Swart, P.K., 1992. Penetrative calcretes and their stratigraphic implications. Geology, 20:331-334.
Schlager, W., 1981. The paradox of drowned reefs and carbonate platforms. Geol. Soc. Am. Bull., 92:197-211.

Schlager, W., Bourgeois, F., Mackenzie, G., and Smit, J., 1988. Boreholes at Great Isaac and Site 626 and the history of the Florida Straits. In Austin, J.A., Jr., Schlager, W., et al., Proc. ODP, Sci. Results, 101: College Station, TX (Ocean Drilling Program), 425-437.

Simms, M., 1984. Dolomitization by groundwater-flow systems in carbonate platforms. Trans. Gulf Coast Assoc. Geol. Soc., 34:411-420.

Supko, P.R., 1977. Subsurface dolomites, San Salvado. J. Sediment. Petrol., 47:1063-1077.

Swart, P.K., Elderfield, H., and Beets, K., in press, a. The ${ }^{87} \mathrm{Sr} /{ }^{86} \mathrm{Sr}$ ratios of carbonates, phosphorites, and fluids collected during the Bahama Drilling Project cores Clino and Unda: implications for dating and diagenesis. In Ginsburg, R.N. (Ed.), SEPM Contributions in Sedimentology.

Swart, P.K., Elderfield, H., and Ostlund, G., in press, b. The geochemistry of pore fluids from bore holes in the Great Bahama Bank. In Ginsburg, R.N. (Ed.), SEPM Contributions in Sedimentology.

Swart, P.K., Ruiz, J., and Holmes, C., 1987. The use of strontium isotopes to constrain the timing and mode of dolomitization of upper Cenozoic sediments in a core from San Salvador, Bahamas. Geology, 15:262-265.

Vahrenkamp, V.C., Swart, P.K., and Ruiz, J., 1991. Episodic dolomitization of late Cenozoic carbonates in the Bahamas: evidence from strontium isotopes. J. Sediment. Petrol., 61:1002-1014.

Vail, P.R., Mitchum, R.M., Jr., Todd, R.G., Widmier, J.M., Thompson, S., III, Sangree, J.B., Bubb, J.N., and Hatlelid, W.G., 1977. Seismic stratigraphy and global changes in sea level. In Payton, C.E. (Ed.), Seismic Stratigraphy: Applications to Hydrocarbon Exploration. AAPG Mem., 26:49221.

Wilber, R.J., Milliman, J.D., and Halley, R.B., 1990. Accumulation of banktop sediment on the western slope of Great Bahama Bank: rapid progradation of a carbonate megabank. Geology, 18:970-974.

Williams, S.C., 1985. Stratigraphy, facies evolution, and diagenesis of late Cenozoic limestones and dolomites, Little Bahama Bank, Bahamas [Ph.D. dissert.]. Univ. of Miami, Coral Gables.

\section{Ms 166IR-103}

